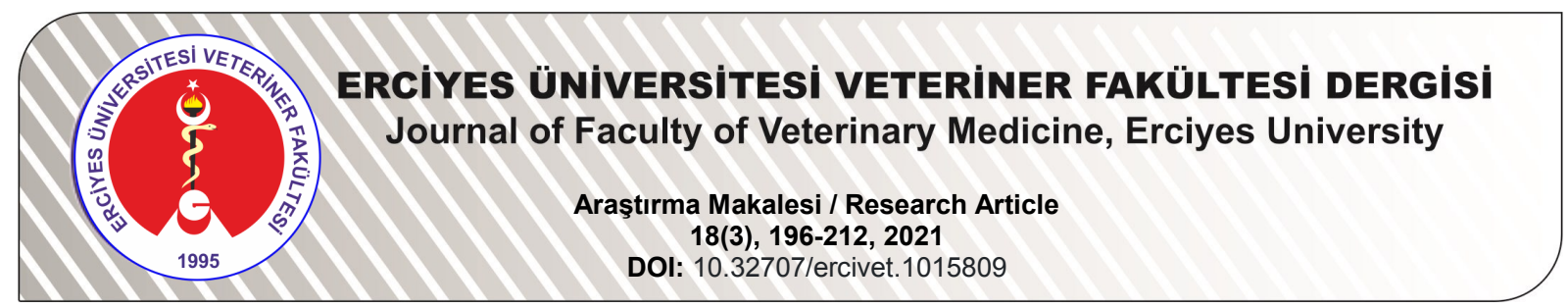

\title{
Erciyes Üniversitesi Veteriner Fakültesi’nin Son On Yıllık (2011-2020) Gelişim Süreci Üzerine Bir Değerlendirme
}

\author{
Çağrı Çağlar SiNMEZ ${ }^{1, a}$, Ali İlteriş AYKUN $N^{1, b}$ \\ ${ }^{1}$ Erciyes Üniversitesi, Veteriner Fakültesi, Veteriner Hekimliği Tarihi ve Deontoloji Anabilim Dalı, Kayseri-TÜRKIYE
} ORCID No: ${ }^{a} 0000-0002-9248-6022 ;{ }^{b} 0000-0002-1986-1519$

Sorumlu yazar: Çağrı Çağlar SiNMEZ; E-posta: cagrisinmez@erciyes.edu.tr

Atıf yapmak için: Sinmez ÇÇ, Aykun Aí. Erciyes Üniversitesi Veteriner Fakültesi'nin son on yıllık (2011-2020) gelişim süreci üzerine bir değerlendirme. Erciyes Univ Vet Fak Derg 2021; 18(3): 196-212

Öz: Bu çalışmada, Türkiye'de veteriner hekimliği eğitim-öğretiminde ilk 25 yılını tamamlayan Erciyes Üniversitesi, Veteriner Fakültesi'nin 2011-2020 yılları arasındaki akademik gelişim ve başarısını ortaya koymak amaçlandı. Çalışmanın materyalini, Erciyes Üniversitesi Rektörlüğü ve Veteriner Fakültesi Dekanlığı'nın ilgili birimlerinin arşivleri, Fakülte öğretim elemanları ile yapılan kişisel görüşmeler ve akademik bilgi formları ile elde edilen veriler oluşturdu. Fakültede, 2020-2021 eğitim-öğretim yılı itibarıyla beş bölüm ve yirmi dört anabilim dalında toplam 82 akademik personelin hizmet verdiği; ulusal ve uluslararası derecelendirmelerde ve bilimsel araştırma ve yayınlarda (makale, bildiri, kitap, atıf ve proje) başarı yüzdesinin yüksek olduğu; mezunların büyük çoğunluğunun kamuda (\%48) ve özel sektörde (\%43) çalıştığı; mezunlarının istihdam oranının ülke ortalamalarının üzerinde olduğu (\%91), işsizlik oranının ise ortalamaların altında yer aldığı (\%6.2); lisansüstü programlardan toplam 146 öğrencinin (25 doktora; 121 yüksek lisans) mezun olduğu belirlendi. Fakültenin tam donanımlı ve modern hayvan hastaneleri ile yılda ortalama on binin üzerinde hayvana veteriner hekimlik hizmeti sunduğu; ulusal ve uluslararası kuruluşlara üye olarak uluslararası standartlarda eğitim-öğretim hizmetlerini yakaladığı söylenebilir. Sonuç olarak, Erciyes Üniversitesi, Veteriner Fakülte'nin, İç Anadolu Bölgesi'nde kamu ve özel sektörlerde faaliyet gösteren diğer kurum ve işletmelerle iş birliği yaparak özelde bölge, genelde ülke hayvan sağlığı ve hayvancılığının gelişimine büyük katkı sağladığı ileri sürülebilir.

Anahtar kelimeler: Akademik faaliyetler, eğitim-öğretim, Erciyes Üniversitesi, Veteriner Fakültesi, veteriner hekimliği tarihi

\section{An Evaluation of the Development Process of Erciyes University Faculty of Veterinary Medicine in the Last Ten} Years (2011-2020)

Abstract: In this study, it is aimed to reveal the academic development and success of Erciyes University Faculty of Veterinary Medicine between 2011 to 2020 , which completed the first 25 years of education in the history of veterinary medicine in Turkey. The material of the study consisted of the archives of the relevant units of the Rectorate of Erciyes University and the Dean of the Faculty of Veterinary Medicine, personal interviews with the faculty members, and the data obtained through academic information forms. In the faculty, as of the 2020-2021 academic year, a total of 82 academic personnel serve in five departments and twenty-four departments; high success rate in national and international rankings and scientific research and publications (articles, papers, books, citations and projects); the majority of graduates work in the public $(48 \%)$ and private sector $(43 \%)$; the employment rate of graduates is above the country average $(91 \%)$, while the unemployment rate is below the average $(6.2 \%)$; It was determined that a total of 146 students (25 doctorate; 121 master's degree) graduated from postgraduate programs. With its fully equipped and modern animal hospitals, the faculty provides veterinary services to more than ten thousand animals annually. It can be said that as a member of national and international organizations, it has achieved education and training services at international standards. As a result, it can be argued that the Erciyes University Faculty of Veterinary Medicine made a great contribution to the development of animal health and animal husbandry in the region in particular, and in the country in general, by cooperating with other institutions and livestock industiries in the public and private sectors in the Central Anatolia Region.

Keywords: Academic activities, education, Erciyes University, history of veterinary medicine, Veterinary Faculty

\section{Giriş}

Erciyes Üniversitesi'nin (ERÜ) kuruluşu, Hacettepe Üniversitesi'ne bağlı olarak açılan Gevher Nesibe Tıp Fakültesi ile 1968 yılında başlamış, 1977 yılında ku-

Geliş Tarihi/Submission Date : 02.08.2021 Kabul Tarihi/Accepted Date : 01.10 .2021 rulan Kayseri İşletme Fakültesi ile devam etmiş, 07.11.1978 tarihli ve 2175 sayılı Kanunla (Resmi Gazete, 1978) Kayseri Üniversitesi adı altında tamamlanmıştır. Kayseri Üniversitesi, ilk olarak 1967'de kurulan Kayseri Yüksek İslam Enstitüsü'nü İlahiyat Fakültesi adı altında, sonrasında 1977'de kurulan Kayseri Devlet Mimarlık ve Mühendislik Akademisi'ni Mühendislik Fakültesi adı altında bünyesine katarak 
1982 yılında Erciyes Üniversitesi adını almıştır (ERÜ Kurumsal Geri Bildirim Raporu, 2017).

ERÜ Veteriner Fakültesi (ERÜVF) 03.07.1992 tarih ve 3837 sayılı Kanun (Resmi Gazete, 1992) ile kurulmuştur. ERÜVF eğitim-öğretim hayatına 1995 yılında ERÜ rektörlük binasındaki derslikte başlamış, 1997-1998 eğitim-öğretim yılı itibarıyla Sümer Kampüsü'nde bulunan eski Mimarlık-Mühendislik Fakültesi binasına taşınmıştır. ERÜVF'nin kurucu dekanı olarak 1995 yılında Prof. Dr. Nejat Aydın atanmıştır. Sonraki dönemlerde sırasıyla Prof. Dr. Tayfur Bekyürek (2001-2004, 2007-2010) ve Prof. Dr. İsmail Hakkı Nur (07.09.2004-07.09.2007) dekanlık görevini yürütmüştür (Özen ve Yüksel, 2011)

Türkiye'de faaliyet gösteren veteriner fakültelerinin kuruluş ve gelişim süreci üzerine bazı araştırmalar yapılmıştır (Yaşar, 1995; Armutak, 2002; Kızıltepe, 2006; Özen ve Yüksel, 2011; Küçükaslan ve Yerlikaya, 2013; Koç Uğurlu, 2015; Türkmenoğlu, 2016). Bu çalışmada, Türkiye'de eğitim-öğretimde ilk 25 yılını tamamlayan ERÜVF'nin akademik birim ve kadrolarına, bilimsel araştırma ve yayın faaliyetlerine, lisans ve lisansüstü eğitim-öğretim durumuna, ulusal ve uluslararası akreditasyon sürecine, eğitim, araştırma ve uygulama hastanesi faaliyetlerine ve dış paydaşlarına ilişkin veriler ile akademik gelişim ve başarısının ortaya konulması amaçlandı. Çalışmada, özelde Türkiye'de veteriner hekimliği eğitim-öğretimine, genelde ise veteriner hekimliği tarihine katkı sağlanması hedeflendi.

\section{Gereç ve Yöntem}

Çalışmanın materyalini, ERÜ Rektörlüğü Yazı İşleri arşivi, ERÜVF Dekanlığı ile Eğitim, Araştırma ve Uygulama Hastanesi arşivi, ERÜ Sağlık Bilimleri Enstitüsü arşivi, fakülte öğretim elemanları ile yapılan kişisel görüşmeler ve akademik bilgi formları ile elde edilen veri ve belgeler oluşturdu. Ayrıca konuyla ilgili çeşitli dergi, kitap, resmi gazete ve internet kaynaklarından faydalanıldı. Veriler içerik analizi yöntemiyle değerlendirildi, metin içerisinde üst simge olarak belirtildi ve son not bölümünde sunuldu.

Çalışmada, mezun veteriner hekimlerin çalıştıkları alan bilgisine; yüz yüze ve telefon görüşmesi yoluyla, sosyal medya platformları aracılığıyla ve Tarım ve Orman Bakanlığı (TOB) personel bilgi veri tabanının taranmasıyla ulaşıldı. ERÜVF'nin kuruluşu ve son on yıllık gelişimini kapsayan eğitim-öğretim ve araştırma konularında elde edilen veriler ilgili bölümlerde tablolar ve şekiller halinde gösterildi.

Çalışmada, araştırma ve yayın faaliyetleri (Tablo 2) ile kayıt yaptıran öğrenci ve mezun sayıları (Tablo 3) ERÜVF'nin ilk 15 yıllık dönemini kapsayan Özen ve Yüksel'in (2011) Erciyes Üniversitesi Veteriner Fakültesinin Kuruluşu ve Gelişim Süreci. başlıklı bilimsel makalesinde açık ve ayrıntılı olarak verilmediği ve yazarlar tarafından yapılan kontrollerde farklı verilerle karşılaşıldığı için 1995-2020 yıllarını kapsayacak şekilde Tablo 2 ve 3'te geniş olarak sunuldu.

\section{Bulgular}

\section{Akademik birimler ve kadrolar}

ERÜVF eğitim-öğretim hayatına 1995 yılında ERÜ rektörlük binasındaki derslikte başlamış ve uzun yıllar Sümer Kampüsü'nde bulunan eski MimarlıkMühendislik Fakültesi binasında sürdürmüştür. Tes-İş Sendikası tarafından yapımı tamamlanan ERÜ Merkez Kampüs içindeki yeni hizmet binasına (Şekil 1) 2011 yılında taşınmış ve halen bu binada akademik faaliyetlerini sürdürmektedir. ERÜVF'nin kurucu dekanı olarak 1995 yılında Prof. Dr. Nejat Aydın ile başlayan yönetim kadrosunda bu dönemde sırası ile dekan olarak 28.03.2011-06.09.2013 tarihleri arasında vekâleten Prof. Dr. Halit Canatan, 09.09.201315.11.2017 tarihleri arasında Prof. Dr. İhsan Keleş yürütmüş ve 16.11.2017 tarihinden bugüne (01.10.2021) Prof. Dr. Abdullah İnci yürütmektedir. ${ }^{1}$

ERÜVF'nin bina taban alanı $2545.67 \mathrm{~m}^{2}$, toplam yapı alanı $14444.70 \mathrm{~m}^{2}$ dir. $47500 \mathrm{~m}^{2}$ ise genel itibari ile fakülte binalarının çevresini oluşturmaktadır. 2021 yılında yapımına başlanacak olan "Hayvan Hastanesi Ek Binasının" taban alanı $3148.00 \mathrm{~m}^{2}$, toplam yapı alanı $4483.20 \mathrm{~m}^{2}$ olarak projelendirildi. Fakülte yerleşkesinde $200 \mathrm{~m}^{2}$ 'lik bir öğrenci kafeteryası da bu-

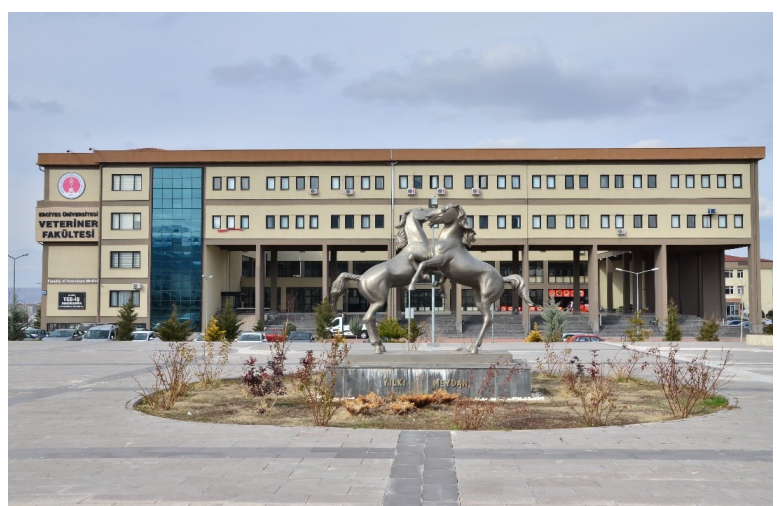

Şekil 1. Erciyes Üniversitesi Veteriner Fakültesi'nin merkez kampüsteki yeni binası (2011-mevcut bina).

lunmaktadır. $^{2}$

ERÜVF ana hizmet binasında sekiz derslik, bir okuma salonu, dokuz öğrenci uygulama laboratuvarı, bir bilgisayar laboratuvarı, dört öğrenci beceri laboratuvarı, yirmi sekiz laboratuvar, dört seminer salonu ve iki konferans salonu bulunmaktadır. Fakültede, bir fakülte sekreteri, bir hastane müdürü, beş veteriner hekim, iki şef, yedi bilgisayar işletmeni, üç memur, altı hizmetli, on destek personeli, beş sağlık teknikeri, iki sağlık teknisyeni, bir laborant, iki teknisyen, iki 
büro işçisi olmak üzere toplam kırk yedi idari personel hizmet vermektedir. ${ }^{3}$

ERÜVF eğitim-öğretime üç bölüm ve toplam 20 ana bilim dalı ile başlamış, ilerleyen süreçte Fakülte bünyesinde iki bölüm (Klinik Öncesi Bilimler, Gıda Hijyeni ve Teknolojisi) ve dört anabilim dalı daha kurulmuştur. Bunlardan, Su Ürünleri ve Hastalıkları Anabilim Dalı'nın açılmasıyla ilgili sunulan teklif, 29.03.2012 tarihli Yükseköğretim Yürütme Kurulu toplantısında incelenmiş ve 2547 sayılı Kanun'un 2880 sayılı Kanun'la değişik 7/d-2 maddesi uyarınca uygun görülmüştür. ${ }^{4}$ Veteriner Halk Sağlığı Anabilim Dalı, 29.08.2012 tarihinde kurulmuş olup, 2012-2013 eğitim-öğretim yılında Gıda Hijyeni ve Teknolojisi Bölümüne bağlı olarak faaliyet göstermeye başlamıştır. ${ }^{5}$ Laboratuvar Hayvanları Bilimi Anabilim Dalı, 04.07.2013 tarihinde Veteriner Fakültesi bünyesinde kurulmuş olup, kendi alanında fakülte bünyesinde kurulan ilk anabilim dalı olma özelliğine sahiptir. ${ }^{6}$ Fakültede en son Yabani Hayvan Hastalıkları Anabilim Dalı, Yükseköğretim Kurulu Başkanlığı'nın 04.05.2021 tarihli ve 33004 sayılı yazısı uyarınca kurulmuştur. $^{7}$

Fakülte 2020-2021 eğitim-öğretim yılı itibarıyla beş bölüm ve yirmi dört anabilim dalında 38 profesör, 15 doçent, 12 doktor öğretim üyesi, 16 araştırma görevlisi ve 1 öğretim görevlisi olmak üzere toplam 82 akademik personel ile eğitim-öğretim faaliyetlerine devam etmektedir. ${ }^{8}$ ERÜVF, Türkiye'deki veteriner fakülteleri arasında öğretim elemanı sayısı bakımından 11. sırada yer alarak mevcut öğretim elamanı sayısının ( $n=1958)$ \%4'ünü oluşturmaktadır (Tablo 1).

ERÜVF Temel Bilimler Bölümü Biyokimya Anabilim Dalı laboratuvarında protein ve lipoprotein elektroforezi, antioksidan enzimler, PCR ve diğer moleküler teknikler ile analizler'; Fizyoloji Anabilim Dalı laboratuvarında hematolojik parametrelerinin tayini ile kliniklerdeki teşhislere destek olacak analizler yapılmaktadır. ${ }^{10}$

Klinik Öncesi Bilimler Bölümünden Farmakoloji ve Toksikoloji Anabilim Dalı laboratuvarında yemlerde mikotoksinler ile süt ve süt ürünlerinde aflatoksin, yem, su ile hayvansal ürünlerde (sucuk gibi) nitrat ve nitrit, insan tüketimine sunulan gıdalarda (et, iç organ ve süt ürünlerinde) antibiyotik ve hormon kalıntıları ile ilgili analizler yapılmaktadır. ${ }^{11}$ Mikrobiyoloji Anabilim Dalı laboratuvarında, büyük-küçükbaş, kanatlı ve pet hayvanlarının bakteriyel ve mikotik enfeksiyonlarının

Tablo 1. Türkiye'de aktif olarak eğitim-öğretim faaliyetlerini sürdüren Veteriner Fakültelerinin yerleşik kadrolarında görev alan öğretim elemanlarının güncel akademik unvanlarına göre sayısal dağılımı

\begin{tabular}{|c|c|c|c|c|c|c|}
\hline Üniversiteler & Prof. & Doç. & Dr. Öğr. Üy. & Araş. Gör. & Öğr. Gör. & Toplam \\
\hline Afyon Kocatepe Üniversitesi & 41 & 14 & 15 & 16 & 2 & 88 \\
\hline Aksaray Üniversitesi & 7 & 9 & 12 & 6 & 2 & 36 \\
\hline Ankara Üniversitesi & 73 & 27 & 5 & 42 & 4 & 151 \\
\hline Aydın Adnan Menderes Üniversitesi & 53 & 14 & 17 & 20 & 4 & 108 \\
\hline Atatürk Üniversitesi & 26 & 16 & 15 & 24 & 0 & 81 \\
\hline Balıkesir Üniversitesi & 16 & 12 & 10 & 7 & 0 & 45 \\
\hline Bingöl Üniversitesi & 9 & 3 & 6 & 15 & 1 & 34 \\
\hline Burdur Mehmet Akif Ersoy Üniversitesi & 35 & 20 & 26 & 8 & 11 & 100 \\
\hline Bursa Uludağ Üniversitesi & 67 & 24 & 10 & 16 & 0 & 117 \\
\hline Çukurova Üniversitesi & 11 & 4 & 9 & 2 & 0 & 26 \\
\hline Dicle Üniversitesi & 12 & 14 & 9 & 9 & 2 & 46 \\
\hline Dokuz Eylül Üniversitesi & 2 & 2 & 4 & 4 & 2 & 14 \\
\hline Erciyes Üniversitesi & 38 & 15 & 12 & 16 & 1 & 82 \\
\hline Fırat Üniversitesi & 69 & 14 & 2 & 29 & 0 & 114 \\
\hline Harran Üniversitesi & 18 & 10 & 19 & 11 & 0 & 58 \\
\hline Hatay Mustafa Kemal Üniversitesi & 22 & 13 & 19 & 18 & 2 & 74 \\
\hline İstanbul Üniversitesi & 75 & 38 & 2 & 40 & 1 & 156 \\
\hline Kafkas Üniversitesi & 35 & 19 & 17 & 15 & 0 & 86 \\
\hline Kastamonu Üniversitesi & 1 & 6 & 6 & 2 & 0 & 15 \\
\hline Kırıkkale Üniversitesi & 26 & 11 & 15 & 9 & 3 & 64 \\
\hline Muğla Sıtkı Koçman Üniversitesi & 3 & 1 & 10 & 2 & 0 & 16 \\
\hline Necmettin Erbakan Üniversitesi & 1 & 0 & 2 & 0 & 0 & 3 \\
\hline Ondokuz Mayıs Üniversitesi & 41 & 27 & 9 & 32 & 0 & 109 \\
\hline Selçuk Üniversitesi & 86 & 15 & 7 & 19 & 2 & 129 \\
\hline Siirt Üniversitesi & 5 & 6 & 10 & 14 & 0 & 35 \\
\hline Sivas Cumhuriyet Üniversitesi & 9 & 9 & 18 & 11 & 0 & 47 \\
\hline Tekirdağ Namık Kemal Üniversitesi & 7 & 8 & 13 & 4 & 1 & 33 \\
\hline Van Yüzüncü Yıl Üniversitesi & 32 & 11 & 25 & 8 & 1 & 77 \\
\hline Yozgat Bozok Üniversitesi & 0 & 2 & 5 & 6 & 0 & 13 \\
\hline
\end{tabular}

Prof.: Profesör; Doç.: Doçent; Dr. Öğr. Üy.: Doktor Öğretim Üyesi; Araş. Gör.: Araştırma Görevlisi; Öğr. Gör.: Öğretim Görevlisi Not: Sayısal veriler her bir Veteriner Fakültesinin web sitesi (akademik kadro) ve akademik veri yönetim sistemlerinden 14.05.2021 tarihinde alıntılanarak hazırlandı. 
Tablo 2. ERÜVF Anabilim Dalları öğretim elemanlarının 1995-2020 yılları arası araştırma ve yayın faaliyetleri

\begin{tabular}{|c|c|c|c|c|c|c|c|c|c|c|c|c|}
\hline \multirow[b]{2}{*}{$\begin{array}{l}\text { Anabilim } \\
\text { Dalları }\end{array}$} & \multicolumn{3}{|c|}{ Makaleler ${ }^{*}$} & \multicolumn{2}{|c|}{ Bildiriler } & \multicolumn{2}{|c|}{$\begin{array}{c}\text { Kitap } \\
\text { Bölümleri }\end{array}$} & \multicolumn{3}{|c|}{ Atıflar } & \multirow[b]{2}{*}{ Ödüller } & \multirow[b]{2}{*}{ Patent } \\
\hline & $\begin{array}{l}\mathrm{SCl}, \\
\text { SSCI } \\
\text { ve SCI } \\
-\mathrm{E}\end{array}$ & Alan & Ulusal & Ulusal & $\begin{array}{l}\text { Ulus- } \\
\text { larara } \\
\text { sı }\end{array}$ & Ulusal & $\begin{array}{l}\text { Ulus- } \\
\text { larara } \\
\text { sı }\end{array}$ & $\begin{array}{l}\mathrm{SCl}, \\
\mathrm{SSCl} \\
\text { ve SCI } \\
-\mathrm{E}\end{array}$ & Alan & Ulusal & & \\
\hline Anatomi & 34 & - & 52 & 33 & 22 & 6 & - & 61 & 71 & 11 & 4 & 1 \\
\hline Biyokimya & 38 & 11 & 24 & 19 & 36 & - & - & 291 & 187 & 156 & 2 & - \\
\hline $\begin{array}{l}\text { Fizyoloji } \\
\text { Histoloji } \\
\text { ve }\end{array}$ & 17 & 9 & 1 & 13 & 25 & - & - & 230 & 326 & 40 & - & - \\
\hline $\begin{array}{l}\text { Embriyoloji } \\
\text { Veteriner } \\
\text { Hekimliği } \\
\text { Tarihi ve }\end{array}$ & 91 & - & 26 & 48 & 127 & 6 & 2 & 830 & 341 & 6 & 3 & - \\
\hline $\begin{array}{l}\text { Deontoloji } \\
\text { Laboratuvar } \\
\text { Hayvanları }\end{array}$ & 9 & 9 & 9 & 25 & 18 & 5 & 2 & 23 & 30 & 50 & - & - \\
\hline $\begin{array}{l}\text { Bilimi } \\
\text { İç Hastalık- }\end{array}$ & 9 & 1 & 1 & 6 & 6 & - & - & 30 & 30 & - & 2 & - \\
\hline & 63 & 76 & 57 & 97 & 140 & 23 & - & 1441 & 1063 & & & 1 \\
\hline $\begin{array}{l}\text { Cerrahi } \\
\text { Doğum } \\
\text { ve }\end{array}$ & 52 & - & 67 & 47 & 85 & 12 & - & 434 & 70 & 92 & 3 & - \\
\hline $\begin{array}{l}\text { Jinekoloji } \\
\text { Dölerme } \\
\text { ve Suni }\end{array}$ & 55 & 30 & 30 & 65 & 108 & 20 & - & 257 & 75 & 35 & - & - \\
\hline $\begin{array}{l}\text { Tohumlama } \\
\text { Farmakoloji } \\
\text { ve }\end{array}$ & 48 & 31 & 3 & - & 23 & - & - & 854 & - & - & - & - \\
\hline $\begin{array}{l}\text { Toksikoloji } \\
\text { Mikrobiyo- }\end{array}$ & 119 & - & 51 & 70 & 48 & 3 & 2 & 1359 & 1003 & 182 & 1 & - \\
\hline Ioji & 58 & - & 27 & 58 & 76 & 3 & 7 & 673 & 60 & 50 & & \\
\hline Viroloji & 29 & 1 & 8 & 6 & 45 & 4 & - & 521 & 23 & 59 & 6 & 1 \\
\hline Parazitoloji & 79 & 20 & 192 & 247 & 349 & 90 & - & 1091 & 660 & 136 & 19 & - \\
\hline $\begin{array}{l}\text { Patoloji } \\
\text { Su Ürünleri } \\
\text { ve Hastalık- }\end{array}$ & 98 & - & 75 & 67 & 52 & - & - & 471 & 461 & 15 & - & - \\
\hline $\begin{array}{l}\text { ları } \\
\text { Veteriner }\end{array}$ & 44 & 11 & 11 & 40 & 70 & 1 & - & 323 & 62 & 11 & 4 & - \\
\hline Halk Sağlığı & 60 & - & 79 & - & 6 & 2 & 2 & 146 & 44 & 15 & - & - \\
\hline Genetik & 47 & 24 & 11 & 63 & 107 & - & 1 & 1154 & 116 & 16 & 3 & 1 \\
\hline Biyometri & 42 & 18 & - & 16 & 34 & - & - & - & - & - & 1 & \\
\hline $\begin{array}{l}\text { Zootekni } \\
\text { Hayvan } \\
\text { Sağlığı Eko- } \\
\text { nomisi ve }\end{array}$ & 26 & 19 & 16 & 10 & 25 & - & - & 269 & 363 & - & - & 1 \\
\hline $\begin{array}{l}\text { İşletmeciliği } \\
\text { Hayvan } \\
\text { Besleme ve } \\
\text { Beslenme }\end{array}$ & 27 & - & 39 & 27 & 17 & 1 & - & 120 & 200 & - & - & - \\
\hline Hastalıkları & 88 & 25 & 80 & 24 & 96 & 6 & - & 4126 & 576 & 73 & 3 & - \\
\hline TOPLAM & 1133 & 285 & 859 & 981 & 1515 & 182 & 16 & 14709 & 5761 & 952 & 51 & 5 \\
\hline
\end{tabular}

*Yayımlanan bilimsel makale sayısı hesaplanırken; çok yazarlı çalışmalarda aynı makalenin birden fazla sayılmaması için ilk yazar esas alınmıştır.

teşhisi bakteriyolojik, mikolojik, serolojik veya moleküler yöntemler kullanılarak yapılmaktadır. ${ }^{12}$

Parazitoloji Anabilim Dalında, Protozooloji ve Moleküler Parazitoloji, Helmintoloji ve Seroloji, Entomoloji ve Insektaryum laboratuvarlarında paraziter enfeksiyon- ların mikrobiyolojik, serolojik ve moleküler teşhisi ve parazitlerin identifikasyonları konularında analizler yapılmaktadır. ${ }^{13}$ Patoloji laboratuvarında rutin histopatoloji, histokimya, immunhistokimya ve sitolojik incelemeler yapılmaktadır. ${ }^{14}$ 
Viroloji Anabilim Dalı Moleküler Viroloji ve Hücre Kültür Laboratuvarlarında; viral hastalık tanısı, virus izolasyonu, identifikasyon ve karakterizasyonu, patogenez ve immun yanıtların ölçülmesi, inaktif ve rekombinant aşı geliştirilmesi çalışmaları yapılmaktadır. ${ }^{15}$

Hayvan Besleme ve Beslenme Hastalıkları Anabilim Dalı laboratuvarında yemlerin ham besin madde analizleri, yemlerde nem, kül, fiber, yağ, protein ve azotsuz öz madde miktarları, yemlerin in vitro sindirim dereceleri, sindirim gazlarının (metan-uçucu yağ asitleri) detaylı gaz-kromotografik analizleri ve rasyon programlarının düzenlenmesi gerçekleştirilmektedir. ${ }^{16}$ Su Ürünleri ve Hastalıkları Anabilim Dalı laboratuvarında bakteriyel ve paraziter kaynaklı balık hastalıklarının teşhisi, etkenin tür identifikasyonu (moleküler, konvansiyonel), etkene karşı tedavi protokolleri yapılmaktadır. ${ }^{17}$ Gıda Hijyeni ve Teknolojisi Bölümü laboratuvarı gıda sektörüne yönelik et ve süt ürünlerinde, içme ve doğal kaynak sularında, su ürünlerinde yönetmeliklerde belirtilmiş olan kimyasal, mikrobiyolojik ve moleküler analizler sürdürülmektedir. ${ }^{18} \mathrm{Bu}$ laboratuvarlar TOB tarafından akredite olarak "Veteriner Teşhis ve Analiz Laboratuvarları Çalışma İzni” belgelerini ${ }^{19}$ almıştır. Ayrıca bu laboratuvarlar Türk Akreditasyon Kurumu (TÜRKAK) akreditasyon sürecine dâhil edilmiş olup süreç titizlikle takip edilmektedir.

\section{Bilimsel araştırma ve yayın faaliyetleri}

Bilgi formlarıyla elde edilen veriler doğrultusunda ERÜVF öğretim elemanlarının 1995-2020 yılları arasında uluslararası SCI, SSCI, SCI Expanded gibi indeksli dergilerde 1133, uluslararası alan indekslerine giren dergilerde 285, ulusal hakemli dergilerde 859 makale yayımladığı; ulusal toplantılarda 981, uluslararası toplantılarda 1515 bildiri sunduğu; ulusal ve uluslararası 198 kitap (editör, bölüm yazarı) hazırladığı tespit edildi (Tablo 2). Ayrıca öğretim elemanları tarafından üniversite Bilimsel Araştırma Projeleri (BAP) birimi destekli 535 adet (203'ü yüksek lisans, 70'i doktora, 262'si münferit); TÜBITAK tarafından desteklenen 64 adet; TAGEM destekli 7 adet; DPT destekli 2 adet; yurt dışı kurumlar destekli 6 adet; diğer kurumların desteklediği 4 adet projenin tamamlandığı ve bu projelerden Fakülteye sağlanan fon miktarının $22773436.68 \mathrm{TL}$. olduğu belirlendi. ${ }^{20}$

YÖK tarafından 2017 yılında "İhtisaslaşma ve Misyon Farklılaşması Projesi” kapsamında çeşitli bilimsel endekslere göre belirlenen "Araştırma ve Aday Araştırma Üniversiteleri" ilan edilmiştir. Bu değerlendirmede Türk Üniversiteleri içerisinde ERÜ 11. sırada yer alarak araştırma kapasitesi, kalitesi ve etkileşimi kapsamında Araştırma Üniversitesi olmaya hak kazanarak $^{21}$ büyük bir başarı elde etmiştir. Ayrıca ERÜ, Yükseköğretim Kalite Kurulu (YÖKAK) tarafından "Kurumsal Akreditasyon Programı" kapsamında 5 yıl süreyle "tam akreditasyon" almaya hak kazanan Türkiye'deki ilk beş üniversiteden birisi olmuştur. ${ }^{22}$
ERÜ dünyanın en iyi 50 yaş ve altı üniversiteleri göz önüne alındığında Times Higher Education (THE) Young University Rankings listesine göre, 55 ülkede 1700'den fazla üniversite arasında 201-250. sırada yer almıştır. ERÜ, Türk devlet üniversiteleri arasında 5. sırada konumlanırken, ERÜVF Türkiye'deki veteriner fakülteleri ve ERÜ'deki tüm fakülteler arasında birinci sırada yer almıştır. ${ }^{23}$

ERÜ, Academic Ranking of World Universities (ARWU) 2019 ve 2020 değerlendirmesine göre, dünyada ilk binde (701-800), Türkiye üniversiteleri arasında ilk onda (2-7) yer almıştır. ${ }^{24}$

ERÜ, QS World University Rankings tarafından yapıIan araştırma sonuçlarına göre, gelişmekte olan Avrupa ve Orta Asya ülkelerini kapsayan "En İyi İlk 400 Üniversite" arasında 148. sırada, Türkiye sıralamasında ise 14. sırada yer alarak önemli bir başarıya imza atmıştır. ${ }^{25}$

\section{Veteriner hekimliği lisans eğitim-öğretimi}

ERÜVF, ÖSYM'nin düzenlediği Yükseköğretim Kurumları Sınavı (YKS) sonucunda AYT-SAY puan türüne göre öğrenci almaktadır. ERÜVF "2020 YKS Yükseköğretim Programları ve Kontenjanları Kılavuzu"na göre 2020 YKS Başarı Sırasına (97.819) ve YKS En Küçük Puan (401.932) tercih sıralamasına göre Türkiye Veteriner Fakülteleri içerisinde 10. sırada yer almaktadır. $^{26}$

ERÜVF'de eğitim-öğretime başlanılan ilk yıllarda uygulanan yönetmelik "ERÜ Sınav Yönetmeliği” olmuştur. ${ }^{27}$ ERÜVF'nin ilk “Eğitim-Öğretim ve Sınav Yönetmeliğı” ise 24.04.1996 tarihinde yürürlüğe girmiştir. ${ }^{28}$ $\mathrm{Bu}$ Yönetmeliğin yerini 28.05.2003 tarih ve 25121 sayılı "Sınav Yönetmeliği" 29, daha sonra 04.05.2004 tarih ve 25452 sayılı Yönetmelik ${ }^{30}$ almıştır. Sonraki süreçte uygulamalar 15.06 .2012 tarihli ve 28324 sayılı Resmi Gazete'de yayınlanan "ERÜ Önlisans ve Lisans Eğitim-Öğretim Yönetmeliği”ne göre gerçekleşmiştir. Bugün lisans düzeyinde eğitim-öğretim, ERÜ Senatosu'nun 27.05.2021 ve 10.06.2021 tarihli toplantılarında kabul edilen "Erciyes Üniversitesi Veteriner Fakültesi Eğitim-Öğretim ve Sınav Yönergesi"ne göre devam etmektedir. ${ }^{31}$

ERÜVF’ye 2011-2020 yılları arasında 846 öğrenci, 1995-2020 yılları arasında ise toplam 1658 öğrencinin kaydolduğu belirlendi (Tablo 3). ERÜVF'de 2020-2021 eğitim-öğretim yılında 359'u (\%64.8) erkek, 195'i (\%35.2) kadın olmak üzere kayıtlı 554 öğrenci bulunmaktadır. Fakülteden ilk mezunlarını verdiği 2000 yılında 12 öğrenci, 2021 yılına kadar toplam 957 öğrencinin mezun olduğu ${ }^{32}$, bu mezunların \%82'sinin erkek, \%18'inin ise kadınlardan oluştuğu tespit edildi (Tablo 3).

Çalışmada, ERÜVF öğrencilerinin mezuniyet sonrası çalışma alanları ve istihdam oranlarını tespit etmek 
Tablo 3. ERÜVF'ye kayıt yaptıran öğrenci ve mezun sayıları (1995-2020)

\begin{tabular}{|c|c|c|c|c|c|c|}
\hline & \multicolumn{3}{|c|}{ Kayıt Yaptıran Öğrenci Sayıları } & \multicolumn{3}{|c|}{ Mezun Olan Öğrenci Sayıları } \\
\hline & Kadın & Erkek & Toplam & Kadın & Erkek & Toplam \\
\hline 1995 & 9 & 22 & 31 & - & - & - \\
\hline 1996 & 3 & 28 & 31 & - & - & - \\
\hline 1997 & 8 & 25 & 33 & - & - & - \\
\hline 1998 & 6 & 25 & 31 & - & - & - \\
\hline 1999 & 4 & 28 & 32 & - & - & - \\
\hline 2000 & 3 & 39 & 42 & 3 & 9 & 12 \\
\hline 2001 & 5 & 48 & 53 & 4 & 15 & 19 \\
\hline 2002 & 1 & 52 & 53 & 3 & 20 & 23 \\
\hline 2003 & 9 & 42 & 51 & 4 & 12 & 16 \\
\hline 2004 & 4 & 51 & 55 & 2 & 26 & 28 \\
\hline 2005 & 6 & 58 & 64 & 2 & 29 & 31 \\
\hline 2006 & 12 & 56 & 68 & 1 & 15 & 16 \\
\hline 2007 & 11 & 54 & 65 & 8 & 59 & 67 \\
\hline 2008 & 4 & 63 & 67 & 9 & 51 & 60 \\
\hline 2009 & 15 & 53 & 68 & 3 & 31 & 34 \\
\hline 2010 & 11 & 57 & 68 & 5 & 73 & 78 \\
\hline 2011 & 13 & 55 & 68 & 9 & 49 & 58 \\
\hline 2012 & 19 & 54 & 73 & 8 & 65 & 73 \\
\hline 2013 & 27 & 49 & 76 & 6 & 56 & 62 \\
\hline 2014 & 23 & 52 & 75 & 6 & 39 & 45 \\
\hline 2015 & 27 & 55 & 82 & 13 & 28 & 41 \\
\hline 2016 & 29 & 51 & 80 & 15 & 38 & 53 \\
\hline 2017 & 20 & 61 & 81 & 13 & 45 & 58 \\
\hline 2018 & 24 & 75 & 99 & 20 & 41 & 61 \\
\hline 2019 & 40 & 56 & 96 & 6 & 15 & 21 \\
\hline 2020 & 58 & 58 & 116 & 36 & 65 & 101 \\
\hline TOPLAM & $391(\% 24)$ & $1267(\% 76)$ & $1658(\% 100)$ & $176(\% 18)$ & $781(\% 82)$ & $957(\% 100)$ \\
\hline
\end{tabular}

amacıyla 2000-2020 yılları arasında mezun olan 957 kişinin 915'ine (\%95.6'sı) ulaşılmıştır. Mezunların \%48'inin kamuda çalıştığı (TOB, $n=360$; üniversiteler, $n=46$; belediyeler, $n=17$; diğer kamu, $n=13$ ), \%43'ünün özel sektörde çalıştığı (büyükbaş hayvan kliniği, $n=223$; pet kliniği, $n=96$; çiftlik hekimi, $n=17$; gıda sektörü, $n=17$; kanatlı sektörü, $n=15$; diğer özel sektör, $n=28), \% 2.8$ 'inin $(n=26)$ sektör dışında çalıştığı, \%6.2'sinin ( $n=57)$ ise herhangi bir istihdam alanında çalışmadığı tespit edilmiştir. Mezunların çalıştıkları alanlara göre dağılımını gösteren oranlar Şekil 2'de sunulmuştur.

ERÜVF, verimli eğitim-öğretimin tamamlayıcısı olarak gördüğü staj eğitimine büyük önem vermektedir. Bu bağlamda; ERÜ Senatosunun 27.05.2021 tarihli ve 11 sayılı toplantısında "ERÜVF Staj (Denetimli Çalışma) Esasları" ${ }^{33}$ kabul edilmiştir. Buna göre, ERÜVF öğrencileri, 4. yarıyıl sonunda (Staj I) laboratuvarlarda ve çiftliklerde, kamu ve özel kuruluşlarda; 6 . yarıyıl sonunda (Staj II) zootekni, hayvan besleme alanlarındaki kamu ve özel kuruluşlarda 5 iş günü; 8 . yarıyıl sonunda (Staj III) klinik bilimler, gıda hijyeni ve teknolojisi alanlarındaki kamu ve özel kuruluşlarda 20 iş

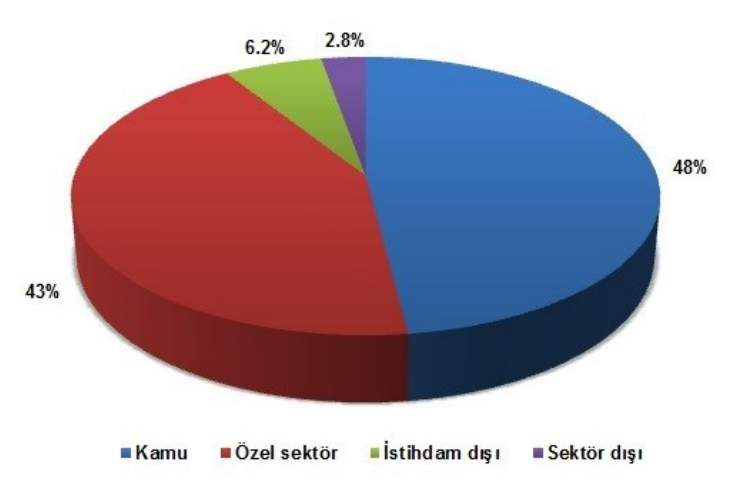

Şekil 2. Mezunların çalıştıkları alanlara göre dağılımı.

günü staj yapmakla sorumlu tutulmuşlardır.

ERÜVF öğrencileri, başta ERASMUS programı çerçevesinde yurtdışında anlaşmalı üniversitelerde bir ya da iki dönem eğitim-öğretim görebilmenin yan sıra, yaz stajlarını da tamamlayabilmektedirler. ERASMUS kapsamında yurtdışına giden öğrenci sayısı üçtür. ${ }^{34}$ Mevlana Değişim Programı ile fakülte- 
ye giden-gelen öğrenci bulunmaz iken 2014-2015 akademik yılında bir akademik personel bu değişime katılmıştır. ${ }^{35}$ Farabi Değişim Programı kapsamında son altı yılda Fakülteye iki öğrenci gelmiş olup, on bir öğrenci ise bu program aracılığı ile eğitimöğretimlerine bir süre başka bir yükseköğretim kurumunda devam etmişlerdir. ${ }^{36}$

\section{Veteriner hekimliği lisansüstü eğitim-öğretimi}

ERÜ Sağlık Bilimleri Enstitüsü (ERÜSBE), 20.07.1982 tarihinde Rektörlüğe bağlı olarak kurularak 1982-1983 eğitim öğretim döneminde faaliyetlerine başlamıştır. ${ }^{37}$

ERÜSBE bünyesinde ilk veteriner programından mezun verdiği 2001 yılından 2020 yılına kadar doktora programlarından 49 kişi; yüksek lisans programlarından 263 kişi mezun olmuştur. ERÜSBE, 2011-2020 yılları arasında 6'sı kadın, 19'u erkek toplam 25 doktora öğrencisi; 37'si kadın, 84'ü erkek olmak üzere toplam 121 yüksek lisans öğrencisi mezun vermiştir. Bu süreçte programlardan 43'ü kadın (\%29), 103'ü (\%71) erkek olmak üzere toplamda 146 öğrenci mezun olmuştur (Tablo 4). Halen Enstitü bünyesinde 39'u kadın 76'sı erkek öğrenci doktora, 78'i kadın 171 'i erkek öğrenci yüksek lisans eğitimine devam etmektedir. Bunlardan YÖK tarafından başlatılan 100/2000 programı kapsamında 13 doktora öğrencisi ERÜVF'de öncelikli alanlarda öğrenimlerine devam etmektedir. $^{38}$

\section{Erciyes Üniversitesi Veteriner Fakültesi Dergisi}

ERÜVF Dergisi, Nisan, Ağustos ve Aralık aylarında olmak üzere yılda üç kez yayımlanan, hakemli ve süreli bilimsel bir dergidir. ERÜVF Dergisi, bugün Web of Science tarafından görünür hale gelmiş, başlıca TR Dizin, Zoological Record, CAB Abstracts olmak üzere birçok ulusal ve uluslararası indeksler tarafından taranmaktadır. ${ }^{39}$

Prof. Dr. Abdullah İnci'nin editörlüğünde 2004 yılında yayın hayatına başlamış olan ERÜVF Dergisi'nde 2011-2020 yılları arasında 10 ciltte, toplam 30 sayı yayımlanmıştır. Bu yıllar arasında, dergide çeşitli alanlarda yayımlanan toplamda 210 araştırma makalesi, 84 derleme, 37 olgu sunumu ve 1 adet kısa bildiri bulunmaktadır. Derginin editörlüğünü 2011-2020 yılları içerisinde Doç. Dr. Berrin Kocaoğlu Güçlü (2011), Prof. Dr. Güner Küçük Bayram (2012), Doç. Dr. Savaş Sarıözkan (2013), Prof. Dr. Gültekin Atalan (2014-2018) ve Prof. Dr. Bilal Akyüz (2018-devam ediyor) yürütmüştür. ${ }^{40}$

\section{Ulusal ve uluslararası akreditasyon kurumları ile ilişkiler}

1-Veteriner Hekimliği Eğitim Kurumları ve Programları Değerlendirme ve Akreditasyon Derneği (VEDEK)

Türkiye'de veteriner hekimliği eğitim-öğretim programlarının ulusal düzeyde akreditasyon yetkisi Yükseköğretim Genel Kurulu tarafından Kalite Değerlendirme Tescil Belgesi'ni 02.02.2012 tarihinde alan Veteriner Hekimliği Eğitim Kurumları ve Programları

Tablo 4. Erciyes Üniversitesi Sağlık Bilimleri Enstitüsü'ndeki Veteriner Fakültesine bağlı lisansüstü programlarından 2011-2020 yılları arası mezun olan öğrenci sayıları

\begin{tabular}{|c|c|c|c|c|c|c|}
\hline \multirow{2}{*}{$\begin{array}{l}\text { Sağlık Bilimleri Enstitüsü } \\
\text { Lisans Üstü Programlar }\end{array}$} & \multicolumn{2}{|c|}{ Doktora } & \multirow{2}{*}{ Toplam } & \multicolumn{2}{|c|}{ Yüksek Lisans } & \multirow{2}{*}{ Toplam } \\
\hline & Kadın & Erkek & & Kadın & Erkek & \\
\hline $\begin{array}{l}\text { Vet Farmakoloji-Toksikoloji } \\
\text { (Cumhuriyet Üniversitesi Ortak) }\end{array}$ & - & 2 & 2 & 1 & 2 & 3 \\
\hline Vet. Mikrobiyoloji & - & 1 & 1 & 2 & 1 & 3 \\
\hline Vet. Farmakoloji-Toksikoloji & - & 2 & 2 & 3 & 8 & 11 \\
\hline Vet. Biyokimya & - & - & - & - & 1 & 1 \\
\hline Vet. Besin Hijyeni ve Tek. & - & - & - & 4 & 11 & 15 \\
\hline $\begin{array}{l}\text { Vet. Besin Hijyeni ve Teknolojisi } \\
\text { (Kırıkkale Üniversitesi Ortak) }\end{array}$ & 1 & 1 & 2 & 5 & - & 5 \\
\hline Vet. Doğum ve Jinekoloji & - & 1 & 1 & - & 1 & 1 \\
\hline Vet. Histoloji ve Embriyoloji & - & 1 & 1 & 2 & 2 & 4 \\
\hline Vet. Parazitoloji & 2 & 1 & 3 & 8 & 11 & 19 \\
\hline Vet. Parazitoloji (CÜ. Ortak) & - & 1 & 1 & 1 & & 1 \\
\hline Vet. Patoloji & - & - & - & 1 & 2 & 3 \\
\hline Vet. Patoloji (Selçuk Üniversitesi Ortak) & - & 1 & 1 & - & - & - \\
\hline Vet. Zootekni & 3 & & 3 & 1 & 16 & 17 \\
\hline Vet. Anatomi & - & 1 & 1 & 1 & - & 1 \\
\hline $\begin{array}{l}\text { Vet. Hayvan Besleme ve Beslenme } \\
\text { Hastalıkları }\end{array}$ & - & 4 & 4 & 2 & 11 & 13 \\
\hline Vet. İç Hastalıkları & - & 2 & 2 & 2 & 10 & 12 \\
\hline Vet. Cerrahi & - & 1 & 1 & 3 & 6 & 9 \\
\hline Vet. Dölerme ve Suni Tohumlama & - & - & - & 1 & 2 & 3 \\
\hline Vet. Fizyoloji & - & - & - & - & - & - \\
\hline TOPLAM & $6(\% 24)$ & $19(\% 76)$ & $25(\% 100)$ & $37(\% 31)$ & $84(\% 69)$ & $121(\% 100)$ \\
\hline
\end{tabular}


Değerlendirme ve Akreditasyon Derneği'ne (VEDEK) verilmiştir. $^{41}$

ERÜVF kuruluşunda VEDEK'in 65 numaralı üyesi olup, ilerleyen süreçte VEDEK'e akreditasyon başvurusunda bulunmuştur. Başvuru sonrası VEDEK tarafından yedi kişilik bir değerlendirme takımı oluşturulmuş ve Fakülte yönetimi ile varılan mutabakat sonucunda 18-22 Kasım 2019 tarihleri arasında değerlendirme ziyareti gerçekleştirilmiştir. Yapılan değerlendirmede Fakülteye ait tüm akademik ve idari birimler yerinde incelenmiş, eğitim-araştırma ve yönetimsel hususlarda kanıta dayalı gözlem ve değerlendirmelerde bulunulmuştur. ERÜVF, VEDEK tarafından gerçekleştirilen değerlendirme sürecini başarıyla tamamlamış ve Veteriner Hekimliği Eğitim Kurumları ve Programları Akreditasyon Komitesinin 14 Şubat 2020 tarihli toplantısı sonucunda 2 yıl süreyle "Şartlı Akredite Fakülte" olarak tescillenmiştir. ${ }^{42}$

Türkiye'de Haziran 2021 yılı itibariyle eğitim öğretim faaliyetlerini sürdüren 32 veteriner fakültesinden toplam 7 veteriner fakültesi (Ankara Üniversitesi VF, Ondokuz Mayıs Üniversitesi VF, Fırat Üniversitesi VF, Burdur Mehmet Akif Ersoy Üniversitesi VF, Uludağ Üniversitesi VF, Selçuk Üniversitesi VF ve Adnan Menderes Üniversitesi VF) VEDEK tarafından tam akredite olarak, 3 veteriner fakültesi ise (Kırıkkale Üniversitesi VF, Erciyes Üniversitesi VF, Atatürk Üniversitesi VF) şartlı akredite olarak değerlendirilmiştir. $^{43}$

\section{2-Avrupa Veteriner Hekimliği Eğitim Kurumları Birliği (EAEVE)}

Avrupa'daki veteriner okullarının değerlendirilme süreçleri veteriner okullarının resmi akreditasyon otoritesi olan "Avrupa Veteriner Hekimliği Eğitim Kurumları Birliği" (European Association of Establishments for Veterinary Education-EAEVE) tarafından yürütülmektedir. Türkiye'de EAEVE üyelik ve akreditasyon süreçleri incelendiğinde EAEVE'ye tam veya aday üye olan 13 veteriner fakültesinin akreditasyon sürecini başlattığı (Ankara Üniversitesi VF, İstanbul Üniversitesi Cerrahpaşa VF, Fırat Üniversitesi VF, Uludağ Üniversitesi VF, Erciyes Üniversitesi VF, Selçuk Üniversitesi VF, Kafkas Üniversitesi VF, Adnan Menderes Üniversitesi VF, Mehmet Akif Ersoy Üniversitesi VF, Atatürk Üniversitesi VF, Afyon Kocatepe Üniversitesi VF, Harran Üniversitesi VF, Yüzüncü Yıl Üniversitesi VF) görülmektedir. Bugün bu fakültelerden 3'ünün (Ankara Üniversitesi VF, İstanbul Üniversitesi Cerrahpaşa VF, Aydın Adnan Menderes Üniversitesi VF) approval statüsü sağlayabildiği belirlenmiştir. ${ }^{44}$

ERÜVF, EAEVE'ye 1 Haziran 2004 yılında üye olmuş $^{45}$ ve ilk denetimini 26-30 Kasım 2012 tarihleri arasında gerçekleştirmiştir. Denetim sonrasında o tarihte yürürlükte olan toplam 25 kriterin 10'undan yetersiz bulunmuştur. 2018 yılında yapılan denetim sonrasında ise toplam 90 kriter üzerinden anatomi ve gıda uygulamaları başta olmak üzere toplam 11 alanda övgüye değer bulunmuştur. ${ }^{46}$ ERÜVF ders programı; Eğitim-Öğretim ve Sınav Yönergesi ${ }^{47}$, Klinik Dersleri ve Klinik Nöbeti Uygulamaları ${ }^{48}$, Klinik Beceri Laboratuvarı Dersleri ${ }^{49}$, Intörnlük Eğitimi ve Bitirme Ödevi Dersleri ${ }^{50}$ başlıkları altında EAEVE direktifleri doğrultusunda revize edilmiş, ölçme ve değerlendirme esasları ${ }^{51}$ hazırlanmıştır. EAEVE 2021 yılı Eylül ayı içerisinde Fakülteyi tekrar değerlendirmek için ziyaret edecektir.

\section{Eğitim, Araştırma ve Uygulama Hastanesi}

ERÜVF Eğitim, Araştırma ve Uygulama Hastanesi 25.04.2014 tarihinde hizmete açılan Kayseri'nin ilk ve tek ruhsatlı ${ }^{52}$ hayvan hastanesidir. Bina taban alanı $1487.00 \mathrm{~m}^{2}$, toplam yapı alanı $4289.00 \mathrm{~m}^{2}$ olan ERÜVF Eğitim, Araştırma ve Uygulama Hastanesin$\mathrm{de}^{53} 7$ gün 24 saat pet, egzotik, çiftlik, kanatlı ve yabani hayvanların her türlü muayene, teşhis ile tedavisi yapılmakta ve koruyucu sağlık hizmetleri verilmektedir. ERÜVF Eğitim, Araştırma ve Uygulama Hastanesine faaliyete başladığı 2015 yılından itibaren teşhis ve tedavi amacıyla gelerek kayıt altına alınmış hayvanların toplam sayısının 50179 olduğu tespit edilmiştir. Hastaneye 2015-2020 yılları arasında teşhis ve tedavi amacıyla gelen hayvanların türlerine göre sayısal dağılımı Şekil 3'de verilmiştir. Bu yıllar arasında en fazla kedi (\%40, $n=19.814)$, köpek (\%39, $\mathrm{n}=19.379)$ ve sığır $(\% 13, \mathrm{n}=6756)$ türü hayvanların hastaneye getirildiği belirlenmiştir (Şekil 4).

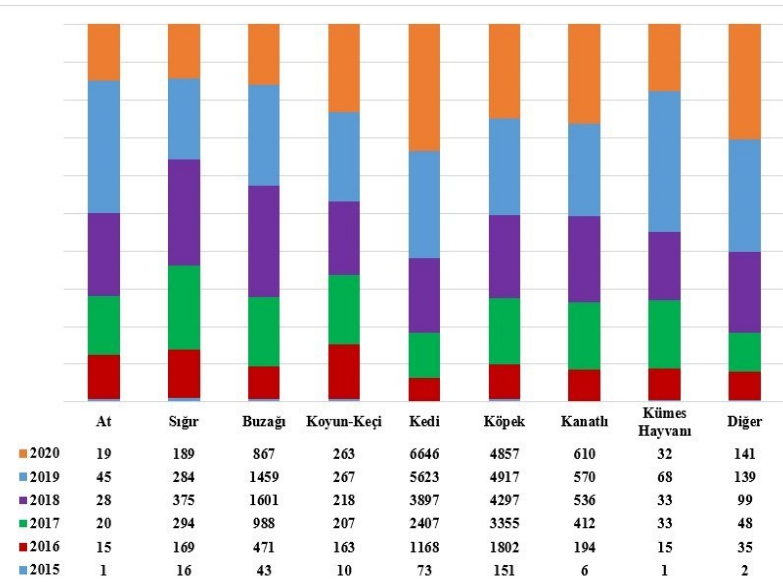

Şekil 3. ERÜVF Eğitim, Araştırma ve Uygulama Hastanesine 2015-2020 yılları arasında teşhis ve tedavi amacıyla gelen hayvan türlerinin sayısal dağılımları.

ERÜVF Eğitim, Araştırma ve Uygulama Hastanesinde hayvanlarla ilgili girişimlerin yapıldığı toplamda üç adet Operasyon Odası, on dört adet Muayene Odası, bir adet Operasyon Hazırlık Odası, bir adet Post Operatif Bakım Odası, bir adet Operatör Hazırık Odası, üç adet Görüntüleme Odası, bir adet Beceri 
Odası, bir adet Aşı Uygulama Odası, bir adet IVF Laboratuvarı, bir adet Yoğun Bakım Odası, bir adet Klinik Teşhis Laboratuvarı, bir adet Fizik Tedavi Ünitesi, bir adet Hasta Hazırlık Odası, bir adet Hasta

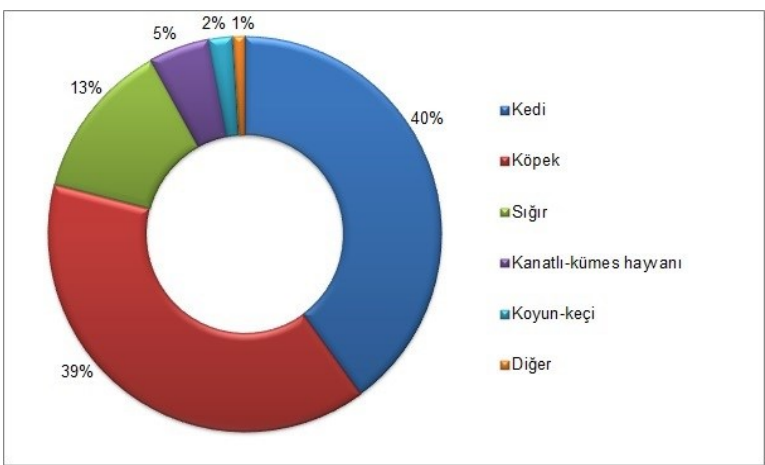

Diğer: At, balık, kemirgen, egzotik ve yabani hayvanlar

Şekil 4. ERÜVF Eğitim, Araştırma ve Uygulama Hastanesine 2015-2020 yılları arasında teşhis ve tedavi amacıyla gelen hayvan türlerinin yüzdelik oranları.

Takip Odası, bir adet Sterilizasyon Ünitesi, bir adet Veteriner Hekim Odası, bir adet Eczane, bir adet Rasyon Hazırlama Odası, bir adet Tıbbi Atık Ünitesi, Hospitalizasyon (at, buzağı, domuz, köpek, kedi, kanatlı ve egzotik) ve İolasyon Odaları ile iki adet Soyunma Odası bulunmaktadır. Hastanede, TOB Gıda ve Kontrol Genel Müdürlüğü tarafından onaylı (izin no: TAL-32, izin tarihi: 27.06.2016) "Veteriner Teşhis ve Analiz Laboratuvarı" ile klinik, tahlil, tetkik ve analiz süreçlerinin yönetimini, kayıtlarını, erişilebilirliğini ve takibini sağlayan güncel entegre tam otomasyonlu hastane yönetim sistemi (ERÜVETO) de bulunmaktadır. ${ }^{54}$

Cerrahi Anabilim Dalı Polikliniğinde, birçok evcil ve yabani hayvan tedavi edilmektedir. Yumuşak doku cerrahisi, ortopedi cerrahisi, göz-kulak cerrahisi, ağızdiş cerrahisi tanı ve tedavi uygulamaları yapılmaktadır. İç hastalıkları Anabilim Dalı Polikliniğinde, pet, egzotik ve çiftlik hayvanlarının enfeksiyöz ve nonenfeksiyöz hastalıkların muayene, teşhis, tedavi ve korumaları, laboratuvar analizleri (tam kan, biyokimya, hormon, idrar vb.) ve aşı uygulamaları yapılmaktadır. Doğum ve Jinekoloji Anabilim Dalı Polikliniğinde evcil hayvanlarda güç doğuma müdahale (normal ve operasyon sezaryen), üreme denetlemesine ilişkin girişimler, dişi genital organ hastalıkları tanı ve tedavileri, küçük-büyük ruminant metabolizma hastalıklarının tanı ve tedavileri gerçekleştirilmektedir. Dölerme ve Suni Tohumlama Anabilim Dalında ise suni tohumlama uygulamaları, döl verimi, döl tutmama sebepleri, sperma muayeneleri ve analizleri konularında araştırmalar yapılmaktadır. ${ }^{55}$

\section{Dış paydaşlar}

Dış paydaşlar, ERÜVF'nin sağladığı ürün ve hizmetlerden yararlanan, faaliyetlerinden doğrudan veya dolaylı bir şekilde etkilenen veya etkileyen kişi, grup veya kurumlardır. Akademik ve idari kadroda çalışanlar ve öğrenciler iç paydaşları; toplum, yetiştiriciler, diğer kurumlar dış paydaşları oluşturmaktadır. Bu bağlamda, ERÜVF İç Anadolu Bölgesi'nde kamu ve özel sektörlerde faaliyet gösteren diğer kurum ve işletmelerle işbirliğini geliştirmek amacı ile protokoller ${ }^{56}$ düzenlemiştir (Tablo 5). Protokollerle, hem hayvan sağlığı ve hayvancılık sektörünün ihtiyacının karşılanması hem de bölge hayvancılığının gelişimini sağlamak ve mevcut sorunların çözümünde yardımcı olmak hedeflenmiştir. ERÜVF, bu protokoller çerçevesinde hem ilgili birimlere veteriner hekimliği hizmetleri götürmekte hem de öğrencilerine eğitim-öğretim gereçlerini sağlamaktadır. 
Tablo 5. ERÜVF ile protokol imzalayan dış paydaşlar

\begin{tabular}{|c|c|c|c|}
\hline Kurum & $\begin{array}{l}\text { Protokol } \\
\text { Başlangıç }\end{array}$ & $\begin{array}{l}\text { Protokol } \\
\text { Bitiş }\end{array}$ & Amaç-Kapsam \\
\hline $\begin{array}{l}\text { Kayseri Su ve Kanalizasyon } \\
\text { İdaresi Genel } \\
\text { Müdürlüğü (KASKi) }\end{array}$ & $10 / 12 / 2020$ & $\begin{array}{l}10 / 12 / 2022 \\
(2 \text { yıllık })\end{array}$ & Eğitim-öğretim ve bilimsel faaliyetler \\
\hline $\begin{array}{l}\text { Tarım ve Orman } \\
\text { Bakanlığı* }\end{array}$ & $15 / 01 / 2020$ & $\begin{array}{l}15 / 01 / 2023 \\
(3 \text { yıllık) }\end{array}$ & $\begin{array}{l}\text { Altyapı, personel eğitim, ARGE, eğitim- } \\
\text { öğretim faaliyetleri }\end{array}$ \\
\hline $\begin{array}{l}\text { Kayseri Valiliği ì Emniyet } \\
\text { Müdürlüğü }\end{array}$ & 03/04/2018 & 03/04/2020 & $\begin{array}{l}\text { Atlı Polis Grup Amirliği ve at çiftliğinde bulu- } \\
\text { nan atların bakımı }\end{array}$ \\
\hline Erkem Et Kesimhanesi & $08 / 02 / 2018$ & $\begin{array}{l}08 / 02 / 2023 \\
(5 \text { yıllık) }\end{array}$ & Eğitim-öğretim ve bilimsel alanlarda işbirliği \\
\hline Molu Kesimhanesi & 08/02/2018 & $\begin{array}{l}08 / 02 / 2023 \\
(5 \text { yıllık })\end{array}$ & Eğitim-öğretim ve bilimsel alanlarda işbirliği \\
\hline $\begin{array}{l}\text { Safiye Çıkrıkçıoğlu } \\
\text { Meslek Yüksekokulu }\end{array}$ & 08/02/2018 & $\begin{array}{l}08 / 02 / 2023 \\
(5 \text { yıllık })\end{array}$ & Eğitim-öğretim ve bilimsel alanlarda işbirliği \\
\hline $\begin{array}{l}\text { Erciyes Üniversitesi } \\
\text { Eczacılık Fakültesi }\end{array}$ & 02/04/2018 & $\begin{array}{l}02 / 04 / 2023 \\
(5 \text { yıllık })\end{array}$ & Eğitim-öğretim ve bilimsel alanlarda işbirliği \\
\hline $\begin{array}{l}\text { Erciyes Üniversitesi } \\
\text { Deneysel Araştırmalar Uy- } \\
\text { gulama ve Araştırma Merke- } \\
\text { zi (DEKAM) }\end{array}$ & $27 / 02 / 2018$ & $\begin{array}{l}27 / 02 / 2023 \\
(5 \text { yıllık })\end{array}$ & $\begin{array}{l}\text { Eğitim kalitesini ve öğrenci uygulamalarını } \\
\text { geliştirmek }\end{array}$ \\
\hline $\begin{array}{l}\text { Kayseri Denetimli } \\
\text { Serbestlik Müdürlüğü }\end{array}$ & $28 / 03 / 2018$ & $31 / 12 / 2019$ & $\begin{array}{l}\text { Kamuya yararlı işte çalıştırılma cezalarının/ } \\
\text { tedbirlerinin/yükümlülüklerinin yerine getiril- } \\
\text { mesi }\end{array}$ \\
\hline $\begin{array}{l}\text { Erciyes Üniversitesi } \\
\text { Tarımsal Araştırma ve Uygu- } \\
\text { lama Merkezi (ERÜTAM) }\end{array}$ & $05 / 12 / 2017$ & $\begin{array}{l}05 / 12 / 2022 \\
(5 \text { yıllık })\end{array}$ & $\begin{array}{l}\text { Eğitim kalitesini ve öğrenci uygulamalarını } \\
\text { geliştirmek }\end{array}$ \\
\hline $\begin{array}{l}\text { T.C Genelkurmay Başkanlığı } \\
\text { Asker Hastanesi Baştabipli- } \\
\text { ği Kayseri }\end{array}$ & 09/10/2015 & Süresiz & $\begin{array}{l}\text { Askeri güvenlik köpeklerinin ilave sağlık } \\
\text { intiyaçlarını karşılamak }\end{array}$ \\
\hline $\begin{array}{l}\text { Kayseri 12'nci Hava Ulaştır- } \\
\text { ma Ana Üs Komutanlığı } \\
\text { (Eski Tarihli) }\end{array}$ & $01 / 04 / 2012$ & Süresiz & $\begin{array}{l}\text { Askeri güvenlik köpeklerinin ilave sağlık } \\
\text { intiyaçlarını karşılamak }\end{array}$ \\
\hline Abalıoğlu Lézita Balık A.Ş & $21 / 12 / 2017$ & $\begin{array}{l}\text { Her yıl oto- } \\
\text { matik yenile- } \\
\text { meli }\end{array}$ & Eğitsel ve bilimsel işbirliğinde bulunmak \\
\hline $\begin{array}{l}\text { Kayseri ì Tarım ve Orman } \\
\text { Müdürlüğü }\end{array}$ & $01 / 01 / 2018$ & $\begin{array}{l}01 / 01 / 2021 \\
(3 \text { yıllık) }\end{array}$ & $\begin{array}{l}\text { Hayvan sağlığı, yetiştiriciliği, beslenmesi, } \\
\text { hayvansal gıdalar, çiftlik yapıları ve araştır- } \\
\text { maları ile ilgili eğitim ve seminer yapııması }\end{array}$ \\
\hline $\begin{array}{l}\text { Kayseri Büyükşehir Beledi- } \\
\text { yesi }\end{array}$ & Tarih yok & (5 yıllık) & Eğitsel ve bilimsel işbirliğinde bulunmak \\
\hline Talas Belediyesi & Tarih yok & (5 yıllık) & Eğitsel ve bilimsel işbirliğinde bulunmak \\
\hline T.C. Talas Kaymakamlığı & Tarih yok & (5 yıllık) & Eğitsel ve bilimsel işbirliğinde bulunmak \\
\hline $\begin{array}{l}\text { Saray Çiftliği Merkez- Da- } \\
\text { mızlık Süt Sığırcılığı İşletme- } \\
\text { leri San. Ve Tic. A.S. }\end{array}$ & Tarih yok & (5 yıllık) & Eğitsel ve bilimsel işbirliğinde bulunmak \\
\hline $\begin{array}{l}\text { Kayseri Yem San. ve Tic. } \\
\text { A.Ş. }\end{array}$ & Tarih yok & (1 yıllık) & Eğitsel ve bilimsel işbirliğinde bulunmak \\
\hline $\begin{array}{l}\text { T.C. Tarım ve Orman Bakan- } \\
\text { lığı Kayseri İI Tarım Ve Or- } \\
\text { man Müdürlüğü }\end{array}$ & 29/01/2018 & $\begin{array}{l}29 / 01 / 2021 \\
(3 \text { yıllık })\end{array}$ & $\begin{array}{l}\text { 4. sınıf öğrencilerinin mezbaha uygulamala- } \\
\text { rı ile ilgili mezbahalara ziyarete ilişkin }\end{array}$ \\
\hline
\end{tabular}




\begin{tabular}{|c|c|c|c|}
\hline Kurum & $\begin{array}{l}\text { Protokol } \\
\text { Başlangıç }\end{array}$ & $\begin{array}{l}\text { Protokol } \\
\text { Bitiş }\end{array}$ & Amaç-Kapsam \\
\hline $\begin{array}{l}\text { Kuzey Kıbrıs Türk Cumhuriyeti } \\
\text { Yakın Doğu Üniversitesi }\end{array}$ & $16 / 01 / 2015$ & $\begin{array}{l}16 / 01 / 2018 \\
(3+3 \text { yıllık })\end{array}$ & Eğitim-öğretim ve bilimsel alanlarda işbirliği \\
\hline $\begin{array}{l}\text { Kayseri Büyükşehir } \\
\text { Belediyesi Kayseri Spor Etkin- } \\
\text { likleri Turizm İnşaat Sanayi ve } \\
\text { Ticaret A. Ş. Genel Müdürlüğü }\end{array}$ & $30 / 09 / 2015$ & (1 yıllık) & $\begin{array}{l}\text { Bakım evleri ve hayvanat bahçelerinde bulunan } \\
\text { hayvanların bakım, tedavi ve hastalıkları ile mü- } \\
\text { cadele }\end{array}$ \\
\hline $\begin{array}{l}\text { Kayseri İ Jandarma Komutanlı- } \\
\text { ğı }\end{array}$ & $11 / 04 / 2014$ & Süresiz & $\begin{array}{l}\text { Askeri hizmet köpeklerinin aşı, kontrol, muayene, } \\
\text { ileri tetkik ve teşhis ve tedavilerine ilişkin }\end{array}$ \\
\hline $\begin{array}{l}\text { NRC Çevre Koruma Atık Yöneti- } \\
\text { mi ve Arıtma Hizmetleri Anonim } \\
\text { Şirketi }\end{array}$ & $13 / 10 / 2014$ & - & $\begin{array}{l}\text { Petrole bulanmış yaban hayvanlarına müdahale } \\
\text { alanında verilebilecek rehabilitasyon ve tedavi } \\
\text { hizmetleri }\end{array}$ \\
\hline İtalya Bologna Üniversitesi & $14 / 04 / 2014$ & $\begin{array}{l}14 / 04 / 2019 \\
(5 \text { yıllık })\end{array}$ & $\begin{array}{l}\text { Öğretim ve araştırma alanında işbirliğini ve sa- } \\
\text { natsal ve kültürel projeleri teşvik etmek }\end{array}$ \\
\hline $\begin{array}{l}\text { Türkiye Atom Enerjisi Kurumu } \\
\text { Sarayköy Nükleer Araştırma ve } \\
\text { Eğitim } \quad \text { Merkezi } \quad \text { (SANAEM) }\end{array}$ & $19 / 0$ & - & $\begin{array}{l}\text { İyonlaştırıcı radyasyon kaynakları ile çalışan per- } \\
\text { sonelin kişisel dozlarının takibi }\end{array}$ \\
\hline
\end{tabular}
(Kişisel Dozimetri Hizmet Sözleşmesi)

T.C. Tarım Ve Orman Bakanlığı 02/04/2012

7. Bölge Müdürlüğü Kayseri Şube Müdürlüğü

Kırgızistan- Türkiye Manas Üni- 18/10/2011 18/10/2016 versitesi Veteriner Fakültesi (Akademik İş Birliği Protokolü)

(5 yıllık)

Bölgede bulunan yaban hayvanlarının bakım tedavilerinin yapılması

Turanlar Çevre Teknolojileri 26/09/2011 Süresiz Mühendislik İnşaat Taahhüt ve

Ticaret Limited Şirketi (Tıbbi Atık Hizmet Protokolü)

Kara Kuvvetleri Komutanlığı 01/11/2010 (1 yıllık) 1'nci Komando Tugay Komutanlığı

Kayseri Valiliği Çevre ve Şehir- 19/06/2009 cilik İ Müdürlüğü

Erciyes Üniversitesi Deneysel 18/06/2009 Araştırmalar Uygulama ve Araştırma Merkezi (DEKAM)

Nevşehir Jandarma At ve Köpek 06/02/2004 Eğitim Merkezi Komutanlığı (JAKEM)

T.C. Hava Kuvvetleri Komutanlı- 03/01/2005 ğı 2'nci Hava İkmal Bakım Merkezi Komutanlığı

TES Tarım, Hayvancılık, Gıda, 13/04/2005 15/03/2006 Tekstil, Oto, Taş., Turizm, İnş., Mad., Sanayi ve Ticaret A.Ş.

Eğitim-öğretim ve bilimsel alanlarda işbirliği ve öğretim üyesi desteği

Tıbbi atıkların toplanması, taşınması ve sterilizasyonu

Gıda ve içecek maddelerinin laboratuvar analizlerinin koordineli olarak yapılması

Yaralı, hasta, bakıma muhtaç yaban hayvanlarının bakım ve tedavileri konusunda işbirliği

Laboratuvar hayvanlarının ilave sağlık hizmetlerinin karşılanması

At ve köpeklerin aşı, kontrol, muayene, ileri tetkik ve teşhis ve tedavilerine ilişkin

Askeri nöbetçi köpeklerinin ilave sağlık intiyaçlarını karşılamak

Tesiste bulunan büyükbaş hayvanların her türlü Veteriner Sağlık Hizmetlerinin karşılanması 


\section{Tartışma ve Sonuç}

Üniversitelerin akademik performanslarını değerlendirmede ele alınan temel kriterler eğitim-öğretim, araştırma ve yayın faaliyetlerinin niteliği ve niceliğidir. ERÜVF'nin 2010-2011 eğitim-öğretim yılı itibariyle akademik kadrosu toplam 50 öğretim elemanından (Özen ve Yüksel, 2011) oluşmakta iken son on yılda bu sayı \%64 artışla 82'e yükselmiştir (Tablo 1). Özen ve Yüksel (2011), ERÜVF'nin ilk 15 yıllık gelişim sürecinde, fakülte akademik kadrosu tarafından uluslararası indekslere giren dergilerde 312, hakemli dergilerde 272 makale yayımlandığı; ulusal toplantılarda 277, uluslararası toplantılarda 101 bildiri sunulduğu; 22 kitap hazırlandığı; BAP, TÜBITAK ve Devlet Planlama Teşkilatı tarafından desteklenen toplam 231 adet projenin tamamlandığını bildirmişlerdir. Çalışmada, ERÜVF öğretim elemanlarının son on yıldaki performansları karşılaştıııldığında ulusal/uluslararası indeksli dergilerde yayımladığı makale, bildiri, kitap, atıf ve proje sayısının çok yüksek (Tablo 2) olduğu görülmektedir. ERÜVF'nin bu yüksek akademik performansının ERÜ'nün Türkiye'de araştırma üniversiteleri arasında yer almasında ve uluslararası üniversite sıralama/derecelendirme kuruluşları tarafından yüksek sıralara yükselmesindeki katkısının çok açık olduğu ileri sürülebilir.

Çalışmada, ERÜVF'de 1995-2020 yılları arasında toplam kayıt yaptıran öğrencilerden erkeklerin oranının (\%76), kadınların oranının (\%24) üç katından daha fazla olduğu, son on yılda ise erkek oranının (\%67), kadın oranının (\%33) yaklaşık iki katı olduğu belirlenmiştir. Ancak kayıt oranı 2019 yılında kadınlar lehine artış göstermiş ve 2020 'de eşitlik sağlanmıştır. Fakülteden 2000-2020 yılları arası mezun olan öğrenciler incelendiğinde ise erkeklerin oranının (\%82), kadınlarının oranının (\%18) yaklaşık beş katı olduğu, son on yılda ise mezun erkek oranının (\%77), kadın oranının (\%23) üç katından fazla olduğu saptanmıştır. Fakültenin 2020 yılı mezunlarında da kadınlar lehine bir artış olduğu gözlemlenmiştir (Tablo 3). Dicle Üniversitesi Veteriner Fakültesinde (DÜVF) 2012-2016 yılları arasında öğrenci profili üzerine yapılan bir araştırma sonucuna göre (Küçükaslan ve Bulut, 2019), kayıt yaptıran öğrencilerden erkeklerin oranının (\%66), kadınların oranının (\%34) yaklaşık iki katı olduğu görülmektedir. Yiğit ve ark. (2014), Kafkas Üniversitesi Veteriner Fakültesi (KAÜVF) 1990-2011 yılları arasındaki mezunlarından erkeklerin oranının (\%89.5), kadınların oranının (\%10.5) yaklaşık 9 katı olduğunu, kadın veteriner hekim oranındaki düşüklüğün, Kars ilinin taşıdığı zor yaşam koşulları ile özellikle küçükbaş ve büyükbaş hayvanlara yönelik saha veteriner hekimliği hizmetlerinin taşıdığı zorluklardan kaynaklandığını bildirmiştir. Benzer şekilde, Başağaç Gül ve ark. (2008), Türk Veteriner Fakültelerinden 2000-2005 yılları arasında mezun olan kadın veteriner hekim oranının ders müfredatında daha çok büyükbaş hayvan hekimliğine ağırlık veren küçük şehirlerde bulunan fakültelerde daha az olduğunu (\%19.3), büyük şehirlerde hizmet veren fakültelerde ise bu oranın yüksek görüldüğünü (\%34.5) bildirmektedir. Bu sonuçlar ile veteriner hekimliği mesleğinin tarihsel süreç içerisinde erkek egemenliğinde olan bir meslek olarak görülmesi nedeniyle kadın öğrenciler tarafından daha az tercih edilmesiyle ilişkilendirilebileceği (Başağaç Gül ve ark., 2008; Küçükaslan ve Bulut, 2019), şehirlerin sosyal, ekonomik ve kültürel gelişiminin ve büyük şehirlerde faaliyet gösteren veteriner fakültelerinin ders müfredatlarının kadın tercihlerinde etkili olabileceği yönünde çıkarım yapılabilir. Bununla birlikte sosyo-ekonomik düzeyde oldukça gelişmiş ve büyükşehir statüsünde olan Kayseri ilinde kurulan ERÜVF'de son yıllarda kadın öğrenci sayısının artmasının yukarıdaki çalışmalarda atfedilen algının değiştiğini göstermesi ve tercih edilme parametrelerini karşılaması açısından önemli bir gelişme olduğu söylenebilir.

OECD (Ekonomik İşbirliği ve Kalkınma Örgütü) üye ülkeleri genelinde yükseköğretim eğitimi almış bireylerin istihdam oranları yüksek olup, \%80'ninden fazlası bir işte çalışmaktadır. Bu oran Türkiye'de yükseköğrenim eğitimi almış kişilerde \%77 olarak görülmüştür (Taş ve Bozkaya, 2012). Türkiye'de, Türkiye İstatistik Kurumu (TÜIK) tarafından yayımlanan rapora göre, 2020 yılında işsizlik oranı \%13.2, istihdam oranı \%42.8 seviyelerinde görülmektedir (TÜIK 2020). TÜIK'in 2020 mezun olunan alana göre işgücü durumunu gösteren verilere bakıldığında, veteriner hekimliğin işsizlik oranı $\% 7.7$, istihdam oranı $\% 75.3$, işgücüne katılma oranı ise \%81.6 olarak tespit edilmiştir (TÜIKK, 2021). Çalışma sonuçlarına göre, ERÜVF mezunlarının işsizlik oranı \%6.2, istihdam oranı \%91, işgücüne katılma oranı ise $\% 93.8$ olarak bulunmuştur. Bu sonuçlara göre, ERÜVF mezunlarının iş bulma oranlarının OECD üye ülkeleri ve TülK verilerine göre ortalamaların üstünde yer aldığı görülmektedir.

Yükseköğretimde kalite güvence sistemlerinin bir parçası mezun izleme çalışmalarıdır. Mezun izleme çalışmaları yükseköğretimin istihdam edilebilirlik ile ilgili değerlendirilmesi için en önemli araçlardan biri ve veri kaynağı olarak görülmektedir (Kalaycı ve Öztürk, 2018; Bakioğlu ve ark., 2011). Kalaycı ve Öztürk'e (2018) göre, mezunlarla ilgili bilgilerin güncel olmadığı ya da mezun veri tabanı, kariyer servisleri gibi sistemlerin olmadığı durumlarda, mezunların bilgilerine ulaşmak sosyal paylaşım siteleri, web siteleri ve arama motorları gibi yöntemler kullanılarak yapılmaktadır. Ülkemizde mezunlara ulaşmanın zorluğu ve mezun izleme sistemlerinin yeterince aktif olmaması, mezun izleme çalışmalarının sınırlı örneklemle gerçekleşmesine yol açmaktadır. Yiğit ve ark. (2014), Türkiye'deki Veteriner Fakülteleri mezunlarının tam bir istihdam haritasının çıkarılması ile veteriner hekimliğinde istihdam politikalarına daha akılcı öneriler sunulabileceğini, veteriner hekimliği alanında 
öğrenci ve mezun profili belirleme çalışmaları ile veteriner hekimliği eğitiminin gerek kamu ve gerekse özel sektöre yönelik hizmet alanlarındaki gereksinimleri ve yeterliliklerinin de belirlenmesine önemli bir katkı sağlayacağını ifade etmektedir. Bu çalışmada da mezunlara ulaşma konusunda yaşanan zorluklar bir mezun izleme sisteminin eksikliğini ve intiyacını çok açık bir şekilde ortaya koymaktadır. Bu bağlamda, ERÜVF özelinde de mezunların takibinin ve ilişkilerin geliştirilebilmesi için bir "Mezun Veri Tabanının" oluşturulması önerilebilir.

ERÜVF mezunlarının çalıştıkları alanlara bakıldığında genel olarak \%48'inin kamu sektöründe (en çok TOB, \%39; üniversiteler, \%5; belediyeler, \%2) çalıştığı, \%43'ünün özel sektörde (en çok büyükbaş hayvan kliniği, \%24; pet kliniği, \%10) çalıştığı görülmektedir (Şekil 2). Yiğit ve ark. (2014), KAÜVF'den mezun olan veteriner hekimlerin $(n=1166)$ çoğunluğunun sırasıyla TOB'da (\%50.8), büyükbaş hayvan kliniklerinde (\%26.9), diğer özel sektör hizmetlerinde (\%8.8), üniversitelerde (\%5.8) ve belediyelerde (\%4.6) hizmet vermesinin, bölgenin hayvan varlığı kompozisyonu ile ilişkili olarak üniversite eğitiminin bu alanlarda verilmesinden kaynaklandığını ileri sürmektedir. Demir ve ark. (2016) çalışmasında, Kafkas ve Adnan Menderes Üniversitesi Veteriner Fakültesi öğrencilerinin mezuniyet sonrasında en fazla arzu ettikleri iş/ istihdam alanlarının klinik (\%52), TOB (\%36.7) ve üniversiteler (\%18.4) olduğunu; Küçükaslan ve Bulut (2019), DÜVF öğrencilerinin mezuniyet sonrasında \%28'inin klinisyenliği, \%22.8'inin akademisyenliği, $\% 16.8$ 'inin kamu veteriner hekimliğini ve \%4.7'sinin belediye veteriner hekimliğini düşündüklerini tespit etmiştir. Yaşar ve ark.nın (2019), Selçuk Üniversitesi Veteriner Fakültesi 1989-2015 yılları arası mezunlarına yönelik yaptığı anket sonuçlarına göre, mezunların en çok TOB'da (\%37), kliniklerde (\%33) ve üniversitelerde (\%8) çalıştığı belirlenmiştir. Göktolga ve Gökalp (2012), Türkiye'de en fazla rağbet gören iş tercihlerinin sırasıyla akademisyenlik, devlet memurluğu ve kendi iş yerinde çalışma olarak bildirmiştir. Özen ve ark. (2012), Türkiye'de veteriner hekimliğe ilişkin iş fırsatları ve alanlarına yönelik yaptığı araştırmada, kamu alanının diğer alanlara göre daha tercih edilebilir olduğunu ancak veteriner hekimlerin \%76.9'nun özel sektörün kamu sektörüne kıyasla daha avantajlı olduğunu ifade ettiklerini; 2023 yılı için bu ifadeyi kullanan veteriner hekimlerin oranının ise \%86.9'a yükseldiğini bildirmiştir. Benzer görüşler, Shepherd ve Pikel (2013)'in, Amerikan veteriner okullarında eğitim gören dördüncü sınıf öğrencilerine yönelik yaptığı bir anket çalışmasında da gözlenmiştir. Amerikan okullarında, öğrencilerin ilk istihdam tercihinin en fazla sırasıyla özel sektör (erkeklerin \%65.4'ü ve kadınların \%59.4'ü), lisansüstü eğitim (erkeklerin \%30.3'ü ve kadınların \%36.1'i) ve kamu sektörü (erkeklerin \%3.6'sı ve kadınların \%4.2'si) olduğunu, özel sektörde pet hekimliğinin (erkeklerin \%35.6'sı, kadınların \%37.8'i), büyükbaş hekimliğine (erkeklerin \%10.7'si, kadınların \%2'si) göre daha çok tercih edildiği sonucuna ulaşılmıştır. Chieffo ve ark. (2008), Amerika Birleşik Devletleri'nde yaptıkları diğer bir çalışmada 1989 yılında mezun olan öğrencilerin \%10.7'sinin büyükbaş hekimlik hizmeti sunarken, 2007 yılında bu oranın \%2.2 oranına düştüğünü ifade etmiştir. Çalışmada ERÜVF mezunlarının yukarıdaki yerel ve ülke örnekleminde yapılan çalışma sonuçlarına benzer şekilde en çok kamuda özellikle TOB içerisinde istihdam edildiği tespit edilmiştir. Özel klinik hizmetlerinden büyükbaş klinik hekimliği oranlarında Amerika'daki çalışma sonuçlarından farklı olarak yüksek bir oran gözlemlendiği ortaya çıkmaktadır. Bu oranların başta devletin istihdam politikaları, ülke ve bölge hayvancılığının durumu/gelişimi ile değişebileceği ileri sürülebilir.

İstihdam edilebilirlikle ilgili önemli bir tartışma konusu da mezunların üniversite eğitimi sırasında kazandıkları yeterliklerle ilişkili bir işte çalışıp çalışmadıklarıdır. Avrupa Komisyonu'nun 2014 raporunda, üniversite mezunlarının ortalama \%25'inin sahip oldukları yeterlik düzeyini gerektirmeyen bir iş alanında çalıştıkları bildirilmiştir (Boztunç Öztürk ve ark., 2015). Buna karşın, ERÜVF'den mezun olmuş ve bir işte çalışan mezunların \%91'inin işleri ve mezun oldukları alanın tamamen ilişkili ve \%2.8'inin işleri ve mezun oldukları alanın hiç ilişkili olmadığı (sektör dışı) görülmektedir (Şekil 2). Bu sonuç ERÜVF mezunlarının eğitim gördükleri alanla ilişkili iş bulma fırsatlarının yüksek olduğu şeklinde yorumlanabilir.

ERÜSBE lisansüstü programlardan 2011-2020 yılları arası mezun olan toplam öğrenci sayılarına bakıldığında, en fazla öğrencinin Besin Hijyeni ve Teknolojisi Anabilim Dalı'ndan ( $n=22)$; en az öğrencinin ise Biyokimya $(n=1)$ ve Fizyoloji Anabilim Dalı'ndan $(n=0)$ mezun olduğu görülmektedir (Tablo 4). Başağaç Gül ve ark. (2010), Türkiye'de SBE'lerden 1999-2007 eğitim yılları arasında yüksek lisans ve doktora programlarından mezun olan öğrencilerle ilgili yaptığı çaIışmada, akademik yaşam dışında iş olanaklarının oldukça sınırlı olması dolayısıyla en az Temel Bilimlerden mezun verildiğini, iş bulma olanakları, çalışma koşulları ve kariyer seçiminde etkili olmasından dolayı en fazla mezunun ise Klinik Öncesi Bilimlerinden Gıda Hijyeni ve Teknolojisi Anabilim Dalından verildiğini bildirmektedir. Benzer şekilde Özen ve ark.nın (2012) araştırma sonuçlarına göre, Türkiye'de veteriner hekimlerin, 2023 yılında en fazla öneminin artacağını düşündükleri alanların başında gıda kalitesi ve güvenliğinin geldiği sonucu ortaya çıkmıştır. Bu sonuçlar, veteriner hekimlerin halk sağlığı alanında yetkin ve etkin olarak sorumluluk ve farkındalık sahibi olmaları ile açıklanabilir.

Eğitimde markalaşmanın ölçülebilir parametreleri olup, bunların başında uluslararası standartlara ulaşmak gelmektedir. EAEVE tarafından akredite edilmiş 
Veteriner Fakültesinden mezun olan veteriner hekimlerin diplomaları Avrupa ve pek çok ülkede geçerli kabul edilmekte, denklikleri verilmektedir. Bu durum Avrupa ve pek çok ülkede çalışmayı, araştırma merkezleri ve üniversitelerde görev almayı düşünen veteriner hekimler için önemli bir avantaj sağlamaktadır (Yerlikaya, 2019). Bu sebeplerden dolayı ERÜVF başta EAEVE ve VEDEK'e üye olarak ve sonraki süreçlerde üyelik şartlarını yerine getirerek uluslararası standartlara ulaşmayı hedeflemektedir. Benzer şekilde, son yıllarda Yükseköğretim Programları ve Kontenjanları Kılavuzlarında (YÖK, 2021) ulusal akreditasyon yetkisine sahip (VEDEK) veteriner fakültelerinin belirtilmesi Türkiye'de veteriner fakültelerinde eğitim almak isteyen öğrencilerin tercihini olumlu yönde etkilediğini de söylemek olasıdır.

ERÜVF Eğitim, Araştırma ve Uygulama Hastanesine 2015-2020 yılları arasında teşhis ve tedavi amaçlı yılda ortalama olarak 10 binin üzerinde hayvan getirildiği, bu hayvanlar arasında en çok pet-arkadaş hayvan türlerinin yer aldığı görülmektedir (Şekil 3, 4). Bu rakamlar Fakültenin halk ve hayvan sağlığı ile bölge hayvancılığına katkısının bir göstergesi olarak değerlendirilebilir.

Üniversitelerin en temel karakteristiği markalaşmadır. Kendi markasını yaratmış olan üniversiteler, öğrenci profili ve akademik kadrosu dâhil her türlü konuda temel belirleyicilerdir. Tam bu noktada ERÜ COVID19 salgınında gerek virüs izolasyonu ve gen haritasının çıkarılması gerekse yerli inaktif bir aşı (TURKOVAC) geliştirmesiyle (Aslım ve Yaşar, 2020) kendi markasını yaratmıştır. ERÜVF içerisinde bulunduğu ulusal ve uluslararası akreditasyon süreçlerini başarıyla tamamlayarak markalaşma yolunda emin adımlarla yüksek disiplin ve inançla hızla ilerlemektedir. Kuruluşundan bugüne geçen çeyrek asırlık sürede birçok gelişme periyodunu geride bırakan ERÜVF, bugün en ileri eğitim-öğretim için gerekli laboratuvar ve hayvan hastanesi ile her türlü alt yapı donanımına sahiptir.

Sonuç olarak; ERÜVF'nin ulusal ve uluslararası düzeyde insan ve hayvan sağlığı ile yetiştiriciliğine sağladığı önemli katkıları değerlendirildiğinde; ulusal ve uluslararası derecelendirmelerde üst sıralarda bulunduğu, yurtdışı yayın sayısı (SCl) ve yurtdışı kongreye katılım düzeyinin yüksek olduğu; çok sayıda anabilim dalında lisansüstü eğitim programlarının açık olduğu; mezunlarının bölgedeki kamu ve özel sektörde istihdamı ile hizmet götürdüğü; hayvan hastanesinin 7/24 acil hizmeti ve hospitalizasyon imkânlarıyla teşhis, tedavi ve koruyucu hekimlik uygulamalarını verimli bir şekilde sunduğu; bölgede yer alan kamu ve özel işletmelerle yapmış olduğu protokoller aracılığıyla hayvan sağlığı ve hayvancılığa önemli hizmetler verdiği söylenebilir.

\section{Son not}

${ }^{1}$ ERÜVF Dekanlık Arşivi. Erişim tarihi: 15.04.2021.

${ }^{2}$ ERÜ Rektörlüğü Yapı İşleri ve Teknik Dairesi Mimarı Berkan Kahvecioğlu, Kişisel görüşme, Görüşme tarihi: 11.02.2021.

${ }^{3}$ ERÜVF Dekanlık Arşivi. Erişim tarihi: 05.06.2021.

${ }^{4}$ ERÜVF Dekanlık Arşivi. YÖK Başkanlığının 05.04.2012 tarih ve B.30.0.EÖB.101.03.02 sayılı yazısı.

${ }^{5}$ ERÜVF Veteriner Halk Sağlığı Anabilim Dalı. https:// veteriner.erciyes.edu.tr/anabilimDaliTanitimi.aspx? anabilimDali=18; Erişim tarihi: 06.05.2021.

${ }^{6}$ ERÜVF Laboratuvar Hayvanları Bilimi Anabilim Dalı. https://veteriner.erciyes.edu.tr/ anabilimDaliTanitimi.aspx?anabilimDali=6; Erişim tarihi: 06.05.2021.

${ }^{7}$ ERÜVF Dekanlık Arşivi. YÖK Başkanlığının 04/05/2021 tarih ve E-75850160-104.01.04.0133004 sayılı yazısı.

${ }^{8}$ ERÜVF Akademik Kadro. https:// veteriner.erciyes.edu.tr/kadro.aspx? kadro=2\&veterinerFakultesi $=45$; Erişim tarihi: 06.06.2021.

${ }^{9}$ Prof. Dr. Meryem Eren, Kişisel görüşme, Görüşme tarihi: 14.04.2021.

${ }^{10}$ Prof. Dr. Ebru Çetin, Kişisel görüşme, Görüşme tarihi: 15.04.2021.

${ }^{11}$ Prof. Dr. Murat Kanbur, Kişisel görüşme, Görüşme tarihi: 20.05.2021

${ }^{12}$ Prof. Dr. Fuat Aydın, Kişisel görüşme, Görüşme tarihi: 20.05.2021.

${ }^{13}$ Prof. Dr. Önder Düzlü, Kişisel görüşme, Görüşme tarihi: 21.05.2021.

${ }^{14}$ ERÜVF Patoloji Anabilim Dalı Tanıtımı. https:// veteriner.erciyes.edu.tr/anabilimDaliTanitimi.aspx? anabilimDali=14; Erişim tarihi: 12.04.2021

${ }^{15} \mathrm{Dr}$. Öğretim Üyesi İbrahim Sözdutmaz, Kişisel görüşme, Görüşme tarihi: 19.05.2021.

${ }^{16}$ Prof. Dr. Osman Küçük, Kişisel görüşme, Görüşme tarihi: 21.05.2021

${ }^{17}$ Prof. Dr. Erdal Yılmaz, Kişisel görüşme, Görüşme tarihi: 20.05.2021.

${ }^{18}$ Prof. Dr. Zafer Gönülalan, Kişisel görüşme, Görüşme tarihi: 21.05.2021. 
${ }^{19}$ Veteriner Teşhis ve Analiz Laboratuvarları Çalışma İzni. İzin tarihi: 17.09.2020, İzin No: TAL-32.

${ }^{20}$ ERÜVF Dekanlık Arşivi. Erişim tarihi: 22.07.2021.

${ }^{21}$ YÖK. Araştırma Üniversiteleri. https:// www.yok.gov.tr/Sayfalar/Haberler/2020/yok-tenarastirma-ve-aday-arastirma-universiteleridegerlendirilmesi.aspx; Erişim tarihi: 12.04.2021.

${ }^{22}$ Yükseköğretim Kalite Kurulu (YÖKAK). https:// yokak.gov.tr; Erişim tarihi: 29.07.2021.

${ }^{23}$ The World University Rankings. https:// www.timeshighereducation.com/world-universityrankings/2018/young-university-rankings\#!/page/0/ length/25/sort_by/rank/sort_order/asc/cols/stats; Erişim tarihi: 13.04.2021.

${ }^{24} 2020$ Academic Ranking of World Universities. https://www.shanghairanking.com/rankings/ arwu/2020; Erişim tarihi: 13.04.2021.

${ }^{25}$ Erciyes Üniversitesi. https://www.erciyes.edu.tr/tr/ detay/universitemiz-qs-eeca-2021-siralamasindaen-iyi-400-universite-arasinda-148-sirada-yeraldi/181f4e8c-dd49-eb11-8cc5-0050569e5e21; Erişim tarihi: 06.06.2021.

${ }^{26}$ YÖK Atlas. Yükseköğretim Girdi Göstergeleri (2020 YKS). https://yokatlas.yok.gov.tr/lisans.php? $y=103510429$. Erişim tarihi: 12.05.2021.

${ }^{27}$ ERÜVF 05.10.1995 tarih 04 sayılı Yönetim Kurulu Kararı.

${ }^{28}$ Resmî Gazete. 24.04.1996 tarih ve 22620 sayılı "Erciyes Üniversitesi Veteriner Fakültesi EğitimÖğretim ve Sınav Yönetmeliği. https:// www.resmigazete.gov.tr/arsiv/22620.pdf; Erişim tarihi: 14.04.2021.

${ }^{29}$ Resmî Gazete. 28.05.2003 tarih ve 25121 sayılı Erciyes Üniversitesi Veteriner Fakültesi EğitimÖğretim ve Sınav Yönetmeliği. https:// www.resmigazete.gov.tr/ eskiler/2003/05/20030528.htm. Erişim tarihi: 14.04.2021.

${ }^{30}$ Resmî Gazete. 04.05.2004 tarih ve 25452 sayılı Erciyes Üniversitesi Veteriner Fakültesi EğitimÖğretim ve Sınav Yönetmeliği. https:// www.erciyes.edu.tr/Files/regulation/6f9c2d43-c88343f4-a870-085d2bbb98f0.pdf/; Erişim tarihi: 10.03.2021.

${ }^{31}$ ERÜVF Eğitim-Öğretim ve Sınav Yönergesi. https:// veteriner.erciyes.edu.tr/Uploads/files/Egitim\% 20Ogretim\%20ve\%20Sinav\%20Yonergesi.pdf; Erişim tarihi: 10.04.2021.
${ }^{32}$ ERÜVF Öğrenci İşleri Arşivi. Erişim tarihi: 13.05.2021.

${ }^{33}$ ERÜVF Staj (Denetimli Çalışma) Esasları. https:// veteriner.erciyes.edu.tr/Uploads/files/Staj\% 20Esaslari.pdf; Erişim tarihi: 15.06.2021.

${ }^{34}$ ERÜ Dış İlişkiler Ofisi Başkanlığı. ERASMUS Değişim Programı Koordinatörlüğü 01.07.2021 tarihli ve 81203 sayılı yazısı.

${ }^{35}$ ERÜ Dış İlişkiler Ofisi Başkanlığı. Mevlana Değişim Programı Koordinatörlüğü 15.06.2021 tarihli ve 72559 sayılı yazısı.

${ }^{36}$ ERÜ Dış İlişkiler Ofisi Başkanlığı. Farabi Değişim Programı Koordinatörlüğü 24.06.2021 tarihli ve 77520 sayılı yazısı.

${ }^{37}$ ERÜ Sağlık Bilimleri Enstitüsü. https:// sagens.erciyes.edu.tr/default.asp?sayfa $=3 ; \quad$ Erişim tarihi: 10.03.2021.

${ }^{38}$ ERÜ Sağlık Bilimleri Enstitüsü Arşivi. Erişim tarihi: 11.03.2021.

${ }^{39}$ ERÜVF Dergisi. https://dergipark.org.tr/tr/pub/ ercivet; Erişim tarihi: 03.04.2021.

${ }^{40}$ ERÜVF Dergisi Arşivi. Erişim tarihi: 04.04.2021.

${ }^{41}$ Veteriner Hekimliği Eğitim Kurumları ve Programları Değerlendirme ve Akreditasyon Derneği (VEDEK). Akredite programlar 2019. http://www.vedek.org.tr/ index.php? option=com_content\&view=article\&id=112\&ltemid=98 \&lang=tr; Erişim tarihi: 12.05.2021.

${ }^{42}$ ERÜVF VEDEK Değerlendirme Raporu, 2019. Kayseri, ss.277.

${ }^{43}$ Veteriner Hekimliği Eğitim Kurumları ve Programları Değerlendirme ve Akreditasyon Derneği (VEDEK). Akredite programlar 2019. http://www.vedek.org.tr/ index.php?

op-

tion $=$ com_content $\&$ view $=$ article $\& i d=112 \&$ Itemid $=98$ \&lang=tr; Erişim tarihi: 12.05.2021.

${ }^{44}$ European Association of Establishments for Veterinary Education (EAEVE). EAEVE Establishments' Status.https://www.eaeve.org/ fileadmin/downloads/establishments status/

EAEVE_Establishments_Status_JUNE_2021_app roved_by_ExCom_on_21.06.2021.pdf; Erişim tarihi: 12.07 .2021$.

${ }^{45}$ ERÜVF Dekanlık Arşivi. 01.06.2004 tarihli EAEVE sekreteri Prof. Dr. Boyd Jones imzalı kabul yazısı. Erişim tarihi: 06.04.2021. 
${ }^{46}$ ERÜVF EAEVE Öz-Değerlendirme Raporu, 2018. https://veteriner.erciyes.edu.tr/Uploads/files/ EAEVE\%20(2).pdf; Erişim tarihi: 19.04.2021.

${ }^{47}$ ERÜVF Eğitim Öğretim ve Sınav Yönergesi. 27.05.2021 tarihli ve 11 Karar No'lu ERÜ Senatosu Kararı. https://veteriner.erciyes.edu.tr/Uploads/files/ Egitim\%200gretim\%20ve\%20Sinav\% 20Yonergesi.pdf; Erişim tarihi: 01.07.2021.

${ }^{48}$ ERÜVF Klinik Dersleri ve Klinik Nöbeti Uygulamaları Esasları. 27.05.2021 tarihli ve 11 Karar No'lu ERÜ Senatosu Kararı. https:// veteriner.erciyes.edu.tr/Uploads/files/Klinik\% 20Dersleri\%20ve\%20Klinik\%20Nobeti\% 20Uygulama\%20Esaslari.pdf; Erişim tarihi: 01.07.2021.

${ }^{49}$ ERÜVF Klinik Beceri Laboratuvarı Dersleri Esasları. 27.05.2021 tarihli ve 11 Karar No'lu ERÜ Senatosu Kararı. https://veteriner.erciyes.edu.tr/Uploads/files/ Klinik\%20Beceri\%20Lab_\%20Dersi\%20Uyg_\% 20Esaslari.pdf; Erişim tarihi:01.07.2021.

${ }^{50}$ ERÜVF Veteriner Hekimliği Intörnlük Eğitimi ve Bitirme Ödevi Esasları. 27.05.2021 tarihli ve 11 Karar No'lu ERÜ Senatosu Kararı. https:// veteriner.erciyes.edu.tr/Uploads/files/Vet_\% 20 Hek_\%20Intornluk\%20Egit_\%20ve\%20Bitirme\% 200devi\%20Esaslari.pdf; Erişim tarihi: 01.07.2021.

${ }^{51}$ ERÜVF Ölçme ve Değerlendirme Esasları. 27.05.2021 tarihli ve 11 Karar No'lu ERÜ Senatosu Kararı. https://veteriner.erciyes.edu.tr/Uploads/files/ OI\%C3\%A7me\%20ve\%20Degerl_\%20Esaslari.pdf. Erişim tarihi: 01.07.2021.

${ }^{52}$ Hayvan Hastanesi Ruhsatı. Ruhsat tarihi: 13.02.2017, No: H-52.

${ }^{53}$ Yapı İşleri ve Teknik Dairesi Mimarı Berkan Kahvecioğlu, Kişisel görüşme, Görüşme tarihi: 11.02.2021.

${ }^{54}$ ERÜVF Eğitim Araştırma ve Uygulama Hastanesi Başhekimliği Arşivi. Erişim tarihi: 26.04.2021.

${ }^{55}$ ERÜVF Eğitim Araştırma ve Uygulama Hastanesi Başhekimliği Arşivi. Erişim tarihi: 26.04.2021.

${ }^{56}$ ERÜVF Dekanlık Arşivi. Erişim tarihi: 15.06.2021.

\section{Kaynaklar}

Armutak A. İstanbul Üniversitesi Veteriner Fakültesinin kuruluşu ve ilk on yıllık (1972-1982) gelişimi. İstanbul Üniv Vet Fak Derg 2002; 28(2): 429-45.

Aslım G, Yaşar A. Türkiye'de "COVID-19 özelinde" salgın hastalıklarda veteriner hekimlerin rolü ve önemi. Eurasian J Vet Sci 2020; 36(5): 126-14.
Bakioğlu A, Yüksel M, Akdağ B, Canel AN. Yükseköğretimde mezun izleme sistemi: Marmara Üniversitesi Atatürk Eğitim Fakültesi mezunları üzerine bir araştırma. Yükseköğretim Dergisi 2011; 1 (2): 65-79.

Başağaç Gül RT, Özkul T, Akçay A, Melikoğlu B. Türkiye'de veteriner hekimliği alanında lisansüstü eğitim. Ankara Üniv Vet Fak Derg 2010; 57: 1924.

Başağaç Gül RT, Özkul T, Akçay A, Özen A. Historical profile of gender in Turkish veterinary medicine. JVME 2008; 35: 305-9.

Boztunç Öztürk N, Özberk EH, Kaptı SB, Fındık LY, Gelbal S, Kavak Y. Hacettepe Üniversitesi mezun izleme çalışması. Yükseköğretim Bilim Derg 2015; 5(3): 263-71.

Chieffo C, Kelly AM, Ferguson J. Trends in gender, employment, salary, and debt of graduates of US veterinary medical schools and colleges. J Am Vet Med Assoc 2008; 233: 910-7.

Demir P, Koç Uğurlu A, Arslan ES. Kafkas ve Adnan Menderes Üniversitesi Veteriner Fakültesi öğrencilerinin veteriner hekimlik mesleğine ve istihdam alanlarına yönelik görüşleri. İst Üniv Vet Fak Derg 2016; 42(1): 11-9.

Erciyes Üniversitesi Kurumsal Geri Bildirim Raporu (Nihai Rapor). https://yokak.gov.tr/Common/ Docs/2016KGBR/Kgbr-Erciyes-Universitesi2016.pdf; Erişim tarihi: 12.03.2021.

Göktolga ZG, Gökalp B. İş seçimini etkileyen kriterlerin ve alternatiflerin AHP metodu ile belirlenmesi. CÜ İktisadi İdari Bil Derg 2012; 13(2): 71-86.

Kalaycı N, Öztürk A. Eğitim ve öğretim mezunlarını izleme çalışması: Gazi Üniversitesi örneği. Türk Eğitim Bil Derg 2018; 16(1): 77-103.

Kızıltepe A. Kuruluşundan bugüne Kafkas Üniversitesi Veteriner Fakültesi. I. Ulusal Veteriner Hekimliği Tarihi ve Mesleki Etik Sempozyumu. 30 Mart-1 Nisan, 2006; Elazığ-Türkiye.

Koç Uğurlu A. Adnan Menderes Üniversitesi Veteriner Fakültesi ve Ege Bölgesi hayvancılığına katkıları. Animal Health Prod and Hyg 2015; 4(2): 44450.

Küçükaslan Ö, Bulut İ. Dicle Üniversitesi Veteriner Fakültesinin öğrenci profili üzerine bir araştırma. Dicle Üniv Vet Fak Derg 2019; 12(1): 1-7.

Küçükaslan Ö, Yerlikaya N. Kırıkkale Üniversitesi Veteriner Fakültesinin kuruluşu ve tarihsel gelişimi. Vet Hekim Der Derg 2013; 84(1): 9-18. 
Özen A, Doğan Ö, Başağaç Gül RT, Özkul T, Yüksel $E$. Türkiye'de veteriner hekimliği üzerine araştırmalar: III. İş fırsatları ve sektörel yönelimlere ilişkin görüş ve beklentiler. Kafkas Univ Vet Fak Derg 2012; 18(6): 907-11.

Özen R, Yüksel A. Erciyes Üniversitesi Veteriner Fakültesinin kuruluşu ve gelişim süreci. Erciyes Üniv Vet Fak Derg 2011; 8(2): 91-5.

Resmi Gazete. 18.11.1978 tarihli ve 2175 sayılı Kayseri Üniversitesi Kurulması Hakkında Kanun. https://www.resmigazete.gov.tr/arsiv/16463.pdf/; Erişim tarihi: 12.03.2021.

Resmi Gazete. 03.07.1992 tarihli ve 3837 sayılı Yükseköğretim Kurumlan Teşkilatı Hakkında 41 Sayılı Kanun Hükmünde Kararnamenin Değiştirilerek Kabulüne Dair 2809 Sayılı Kanun ile 78 ve 190 Sayılı Kanun Hükmünde Kararnamelerde Değişiklik Yapılması Hakkında Kanun. https:// www.resmigazete.gov.tr/arsiv/21281.pdf/; Erişim tarihi: 12.03.2021.

Shepherd AJ, Pikel L. Employment of female and male graduates of US veterinary medical colleges, 2013. JAVMA 2013, 243(8): 1122-6.

Taş S, Bozkaya G. Avrupa Birliği uyum sürecinde Türkiye'de uygulanan istihdam politikaları. Kahramanmaraş Sütçü İmam Üniv İktisadi İdari Bil Fak Derg 2012; 2(1): 151-76.

Türkiye İstatistik Kurumu (TÜIK). İşgücü İstatistikleri 2020. https://data.tuik.gov.tr/Bulten/Index? $\mathrm{p}=$ Isgucu-Istatistikleri-2020-37484\#: :text=T\% C3\%BCrkiye\%20genelinde\%2015\%20ve\% 20daha,\%13\%2C2\%20seviyesinde\%20ger\%C3\% A7ekle\%C5\%9Fti; Erişim tarihi: 15.05.2021.

Türkiye İstatistik Kurumu (TÜIK). 29.06.2021 tarihli ve E-27964695-622.03-97488 sayılı yazısı.

Türkmenoğlu $E$. Kuruluşundan günümüze Yüzüncü Yıl Üniversitesi Veteriner Fakültesi. Kocatepe Vet J 2016; 9(2): 70-3.

Yaşar A. Selçuk Üniversitesi Veteriner Fakültesinin kuruluşu ve ilk on yıllık gelişimi. Vet Bil Derg 1995; 11(1): 131-9.

Yaşar A, Aslım G, Tekin ME, Çevrimli MB, Mat B, Tekindal MA. Evaluation in terms of various parameters the Selçuk University Faculty of Veterinary Medicine graduates opinions. Eurasian J Vet Sci 2019; 35(3): 114-21.

Yerlikaya N. Türkiye'de veteriner hekimliği öğretiminde ulusal ve uluslararası akreditasyon kuruluşları, standartları ve değerlendirme süreçleri. I. Uluslararası Sabak Kongresi. 17-19 Ekim, 2019; Ankara -Türkiye.
Yiğit A, Aydın E, Cihan M. Evaluation of graduates of the Kafkas University Faculty of Veterinary Medicine in terms of several parameters. Eurasian $\mathrm{J}$ Vet Sci 2014; 30(4): 166-73.

YÖK. 2020-Yükseköğretim Kurumları Sınavı (YKS) Yükseköğretim Programları ve Kontenjanları Kılavuzu. http://www.osym.gov.tr; Erişim Tarihi: 11.04.2021. 
